\title{
Middle Pleistocene seismically induced clay diapirism in an intraplate zone, western Brittany, France
}

\author{
Van Vliet-Lanoe Brigitte ${ }^{1, *}$, Authemayou Christine ${ }^{1}$, Molliex Stephane ${ }^{1}$, Field Michael Hugh ${ }^{2}$, \\ Frechen Manfred ${ }^{3}$, Le Roy Pascal ${ }^{1}$, Perrot Julie ${ }^{1}$, Andrieu-Ponel Valerie ${ }^{4}$, Gregoire Gwendoline ${ }^{1}$, \\ Hallegouet Bernard ${ }^{5}$
}

1 IUEM, CNRS, UBO, UMR Geosci Ocean 6538, PI N Copernic, F-29280 Plouzane, France.

2 Leiden Univ, Fac Archaeol, Archaeo \& Palaeobot Lab, POB 9515, NL-2300 RA Leiden, Netherlands.

3 Leibniz Inst Angew Geophys, Stilleweg 2, D-30655 Hannover, Germany.

${ }^{4}$ Avignon Univ, Aix Marseille Univ, CNRS, IRD,IMBE, Technopole Arbois Mediterranee,BP 80, F-13545 Aix En Provence, France.

5 UBO, Geog Dept, 40 Rue Commandant Boennec, F-29490 Guipavas, France.

${ }^{*}$ Corresponding author : Brigitte Van Vliet-Lanoë, email address : brigitte.vanv-lietlanoe@univ-brest.fr

\begin{abstract}
:
The Brittany region of France is located in a low seismicity intraplate zone. Most of the instrumented earthquakes are limited to a shallow crustal depth without surface rupture. A paleoseismological analysis was performed on deposits on the Crozon Peninsula and in the Elorn estuary. We highlight hydroplastic deformations induced by liquefaction leading to clay diapirism, which were likely triggered by past earthquakes. This diapirism seems to be frequent in continental nonconsolidated sediments and to develop on the inherited tectonic structures, when a shallow water table and confining layers exist. Timing of deformation is dated using paleoenvironmental data, and electron spin resonance and infraredstimulated luminescence dating methods. Two seismic periods were identified in western Europe during early Marine Oxygen Isotope Stage (MIS) 10 (380 ka) and early MIS 8 (280-265 ka). The lack of similar deformations affecting the Holocene tidal deposits in the Bay of Brest suggests that the magnitude of the triggering paleoearthquakes is probably higher (M-w 6) than the recent events (M-w 5.4). These unusual intraplate major paleoearthquakes need specific factors affecting the far-field crustal stress loading to be triggered, such as a brief acceleration of the Africa-Eurasia lithospheric plate convergence, glacioisostatic stress perturbations associated with the onset of major glaciations in northern Europe, or other processes induced by orbital forcing.
\end{abstract}

Keywords: Clay diapirism, Liquefaction, Earthquake, Saprolite, Brittany, Variscan structures, Paleoseismology, Intraplate, Middle Pleistocene 


\section{INTRODUCTION}

Analyzing the palaeo-seismicity in a low-activity intraplate region is still challenging since most earthquakes are limited to a shallow crustal depth without evidence of rupture at the surface (Landgraf et al., 2016). In general, there is no long (> $1 \mathrm{ka}$ ) paleoseismic record in stable continental regions. Western Europe is an intraplate region, influenced by both the collision between Eurasian and African plates (Ziegler and Dezès, 2006) and glacio-isostatic deformations (Lambeck and Johnston 2000, Marotta et al., 2004). On continental Western Europe very few outcrops allow for the analysis of palaeo-seismicity in Quaternary deposits. In eastern and central Brittany, Neogene and Quaternary deposits are preserved within small valleys or basins (Van Vliet-Lanoë et al., 2002). In southern and western Brittany, such as the Crozon Peninsula and Bay of Brest, the low relief and "blocks and grabens" morphology inherited from the Neogene offer suitable conditions to preserve Quaternary deposits in depressions (Fig. 1). In this region, load casts and plastic deformations are commonly observed in Quaternary deposits and are interpreted as resulting from periglacial activity. Indeed, during the Quaternary glacial stages the region was occupied by discontinuous and/or continuous permafrost, allowing for the development of cryoturbation or the diagenesis of deformed sediments by differential frost heaving and solifluction processes (Van Vliet-Lanoë et al., 2004; Table 1). However, frequent regional load cast figures do not correspond to periglacial criteria of formation, notably due to the absence of traces of ice segregation and of spatial regularity related to the classic control by desiccation polygons $<1 \mathrm{~m}$ (Van Vliet-Lanoë et al., 2004). In Brittany, meter-scale load casts are present in the Aber Ildut valley to the west of Brest, in the Elorn River valley, and on the Crozon Peninsula (Fig. 1B).

Seismic surveys and coring within the Bay of Brest did not permit us to observe deposits older than the Weichselian (Grégoire et al., 2017). However, the Trez Rouz and Pen Hat sections located on the Crozon Peninsula are exceptional sites exhibiting the most complete sections of middle and upper Quaternary units in Brittany. Studying these sites gives us an opportunity to investigate further back in time (from $\sim 400 \mathrm{ka}$ to present). The Trez Rouz site is locally famous because of its wave-like peat deformations, traditionally attributed to periglacial activity (Hallégouët, 1989). As well, the entrance of the Elorn estuary (Fig. 1B) locally provided sediment traps, such as at the Kergleuz sections, which recorded and preserved an important part of the Plio-Quaternary geological history. Sections presented in this study (Fig. 1B) were analyzed from stratigraphic and palaeo-seismic points of view before being compared to other dated sections with similar records: at Pénestin, close to the Vilaine River estuary (Southern Brittany), and at Le Gurp (Gironde River estuary, Aquitaine coast) (Figs. 1A and 2).

In this paper, we aim to define the tectonic, palaeo-environmental, and stratigraphic settings of several deformed Quaternary deposits in order to argue a mechanistic interpretation of the Quaternary deformation processes at the scale of western Brittany. We aim to determine whether non-periglacial deformation might result from local or distal co-seismic liquefaction of clayey saprolite, mud, and sand, because by low magnitude earthquakes with no evidence of surface ruptures presently occur within the study area. Our data will provide a discussion of the processes responsible for the deformation structures, especially clay diapirism. We will also constrain the age of 
deformations with luminescence and palaeo-environmental methods. We rely on the age of these deformations with similar palaeo-seismic events recorded on (or close to) other Variscan structures in Western Europe (Fig. 2). We also discuss these seismic events in the context of plate tectonics, glacio-isostatic mechanisms, and other less constrained processes, such as the impact of earth's rotational velocity and mantle activity on lithosphere unloading.

\begin{tabular}{|c|c|c|c|c|c|}
\hline Deformation & Process & Microfabric & $\begin{array}{l}\text { Local conditions } \\
\end{array}$ & Organisation & orientation \\
\hline $\begin{array}{l}\text { Cryoturbation } \\
\text { (periglacial) }\end{array}$ & $\begin{array}{l}\text { Differential frost ( ice segregation) } \\
\text { heave, positive or negative gradient of frost } \\
\text { susceptiblity } \\
\text { Small diapirs: injection (negative gradient of } \\
\text { frost susceptibility) } \\
\text { Stone jacking }\end{array}$ & $\begin{array}{l}\text { Platy to blocky, } \\
\text { Silty caps, particle } \\
\text { translocation } \\
\text { Surface crusting } \\
\text { (pseudo-liquefaction) }\end{array}$ & $\begin{array}{l}\text { Depression, down slope, moist } \\
\text { to wet } \\
\text { Superficial liquefaction }(<20 \mathrm{~cm})\end{array}$ & $\begin{array}{l}\text { Random adjacent or regular } \\
\text { (thermal or desiccation net) } \\
\text { Decimetre, regular in size }\end{array}$ & None or slope direction \\
\hline $\begin{array}{l}\text { Solifluction } \\
\text { (periglacial) }\end{array}$ & $\begin{array}{l}\text { Differential frost } \\
\text { heave, positive or negative gradient } \\
\text { lateral and downward sliding during thaw } \\
\text { consolidation and drainage } \\
\text { Stone jacking downstream }\end{array}$ & $\begin{array}{l}\text { Platy to granular, } \\
\text { Silty caps, aggregate } \\
\text { rotation, particle } \\
\text { translocation } \\
\text { Surface crusting } \\
\text { (pseudo-liguefaction) }\end{array}$ & $\begin{array}{l}\text { Slope form } 2^{\circ} \text { to steeper } \\
\text { Massive form on drained slope } \\
\text { Stretched form on poorly drained } \\
\text { slope (snow patche } \\
\text { Possible liquefaction at the lower } \\
\text { end }\end{array}$ & $\begin{array}{l}\text { Global from a single surface } \\
\text { or in superponed tongues. }\end{array}$ & $\begin{array}{l}\text { Globally slopeward } \\
\text { Common excepted on } \\
\text { south facing slopes }\end{array}$ \\
\hline $\begin{array}{l}\text { Load cast } \\
\text { (sedimentary) }\end{array}$ & $\begin{array}{l}\text { stratified fast sedimentation with some } \\
\text { contrast in viscosity and density }\end{array}$ & $\begin{array}{l}\text { None specific, } \\
\text { layer rupture }\end{array}$ & Water saturated or underwater & $\begin{array}{l}\text { Random or local } \\
\mathrm{mm} \text { to dm }\end{array}$ & $\begin{array}{l}\text { None or surface stretching } \\
\text { in slope direction }\end{array}$ \\
\hline $\begin{array}{l}\text { Load cast } \\
\text { (single shock) }\end{array}$ & $\begin{array}{l}\text { Impact, stratified sedimentation with some } \\
\text { contrast in viscosity and density } \\
\text { eg. swach, trampling }\end{array}$ & $\begin{array}{l}\text { None specific, } \\
\text { rather massive } \\
\text { layer rupture, } \\
\text { locally kink }\end{array}$ & $\begin{array}{l}\text { Water saturated or shallow } \\
\text { underwater }\end{array}$ & $\begin{array}{l}\text { Local or along a shore } \\
\mathrm{mm} \text { to } \mathrm{m}\end{array}$ & none \\
\hline $\begin{array}{l}\text { Load cast } \\
\text { (earthquake) }\end{array}$ & $\begin{array}{l}\text { Vibration at the surface of stratified } \\
\text { sedimentation with some contrast in viscosity } \\
\text { and density }\end{array}$ & $\begin{array}{l}\text { None specific, } \\
\text { rather massive } \\
\text { layer rupture } \\
\text { wrinkling, } \\
\text { rock clast rotation, } \\
\text { microinjections, } \\
\text { overconsolidation }\end{array}$ & $\begin{array}{l}\text { Water saturated or under } \\
\text { shallow water }(<1 \mathrm{~m}) \text { or above a } \\
\text { shallow water table }(<5 \mathrm{~m} \text { deep })\end{array}$ & $\begin{array}{l}\text { Patchy, in nodal position, } \\
\text { In association with water } \\
\text { escape } \\
\text { mm to decimetre } \\
\text { irregular in size }\end{array}$ & $\begin{array}{l}\text { None to very well, } \\
\text { unidirectional, sinking in } \\
\text { slope direction }\end{array}$ \\
\hline $\begin{array}{l}\text { Large involutions } \\
\text { Folds trains, } \\
\text { Diapirs }\end{array}$ & $\begin{array}{l}\text { One or all the following processes } \\
\text { - earthquake } \\
\text { - compression/tension } \\
\text { - slump ( eg. valley bulging) }\end{array}$ & $\begin{array}{l}\text { Stretching, } \\
\text { overconsolidation } \\
\text { Secondary loads, water } \\
\text { injection, shear, } \\
\text { microfaults }\end{array}$ & $\begin{array}{l}\text { Depression, basin } \\
\text { Wet to shallow water; } \\
\text { in series, } \\
\text { above a shallow water table }(<5 \\
\mathrm{m} \text { deep) }\end{array}$ & $\begin{array}{l}\text { Control by seismic weave } \\
\text { length or basement faults ( or } \\
\text { Riedel) } \\
\text { metric to dm }\end{array}$ & Oriented \\
\hline
\end{tabular}

\section{MATERIAL AND METHODS}

A high-resolution swath bathymetric map of the Bay of Brest obtained by a multibeam echo-sounder survey coupled to a detailed topographic map of the Crozon peninsula and surrounding areas (Litto3D program) are used to locate the most prominent faults controlling the topography. Altitudes are given in meter NGF (French Ordnance Survey, $5 \mathrm{~m}$ NGF corresponding to above the sea level or a.s.l.). A seismic profile (Fig. 3) was also performed to distinguish the offshore continuity of onshore faults at depth. This profile was acquired with a Sparker Source, a six channel SIG streamer, and a numerical DELPH2 acquisition system. The sparker emission energy ranges from 250 to $500 \mathrm{~J}$, the shooting rate is $1.5 \mathrm{~s}$, and the vessel bottom speed is 5 knots. Seismic processing (simple stacking and filtering, Butterworth, 200-800 Hz) was done to enhance data quality with SPW (Parallel Geosciences Corporation) and Seismic Unix softwares.

Palaeoseismological analyses were performed from field observations, descriptions, and regular photographic surveys of coastal sections made from the 1980s onwards, but mostly prior to 1997, the recent access of the sections being restricted because of their location into the Crozon Natural Park (dating on the pictures). 

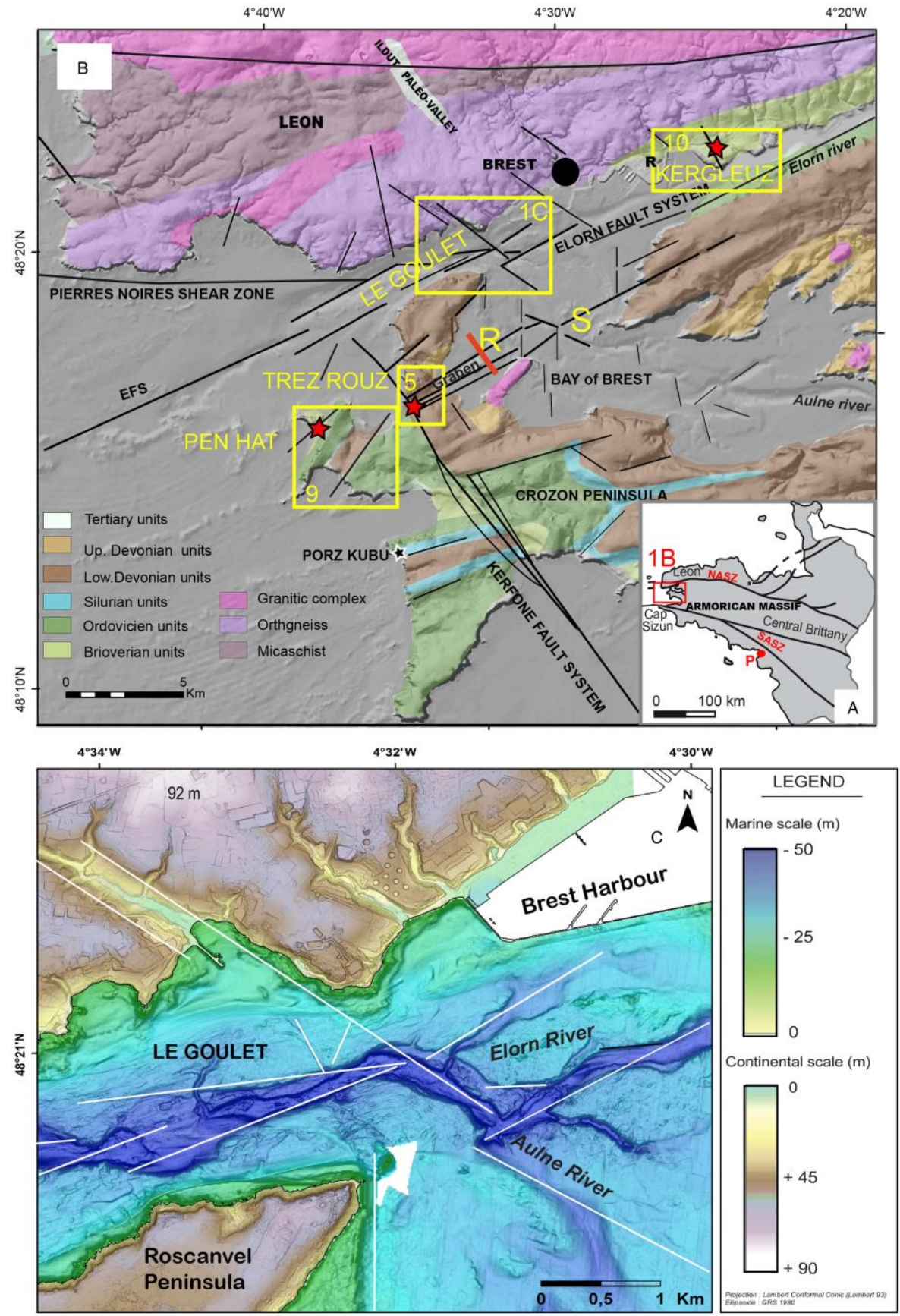

Figure 1. Location of the sections on the Crozon Peninsula and on the Elorn estuary. (A) Location of studied zones in the Armorican Massif framework. $(B, C)$ LIDAR (light detection and ranging) image of the Bay of Brest entrance from the Litto3D LIDAR pictures. Completed for tectonic with data from the geologic map of the Department of Finistère, Bureau de recherches géologiques et minières 2008. P, Pénestin; $R$, sparker seismic profile Roscanvel (see Fig. 8); S, submarine slump. In panel $C$, major faults are in red; secondary faults are in black. (For interpretation of the references to color in this figure legend, the reader is referred to the web version of this article.)

With the present-day rising sea level, coastal environments are either refreshed or degraded, and several successive surveys allow us to constrain the observed deformed structures in 3D. For the Trez Rouz site, first palynological analyses were performed in 1974 by M.T.Morzadec-Kerfourn (Mullenders extraction methodology). A second analysis was made by V.Andrieu-Ponel at the Marseille laboratory using a treatment with a heavy liquid $(\mathrm{d}=2)$ in complement to the sampling for seeds and plant remains (Field et al., 2000). All these data are summarized in Figure 4. 
Dating of the Quaternary units was previously performed by the electron spin resonance (ESR) methods on the Trez Rouz, Pen Hat, and Penestin sections (M. Laurent, in Van Vliet-Lanoë, et al., 1997 and 2009). New infrared stimulated luminescence (IRSL) ages on MIS6 deposits were performed on the Pen Hat section (Table 2). Sand sized K-feldspar minerals were prepared using the standard procedure including dry sieving, treatments with $\mathrm{HCl}$ and $\mathrm{H} 2 \mathrm{O} 2$, and density separation $(\mathrm{d}<2.58)$. The prepared K-feldspar samples with 150-200 $\mu \mathrm{m}$ grain size were mounted on stainless steel discs using silicone oil. Each aliquot contained 10-20 grains. All luminescence measurements were conducted with a Riso TL/OSL DA-20 reader and the luminescence signal was detected through a combination of blue filters (7-59 and BG-39) with a neutral density filter (ND10). The dose rates were calculated by radioactivity measurements of the samples using high-resolution gamma spectrometry. The equivalent dose (De) of the samples were measured using elevated temperature post-IR IRSL (pIRIR), stimulated at $290^{\circ} \mathrm{C}$ after preheating at $320^{\circ} \mathrm{C}$ for $60 \mathrm{~s}$ and with the first IR stimulation at $200^{\circ} \mathrm{C}$. By increasing the first stimulation temperature from the standard $50^{\circ} \mathrm{C}$ (Thiel et al., 2011) to $200^{\circ} \mathrm{C}$, the signal can be considered to be free from anomalous fading (e.g., Ito et al., 2017). Ten aliquots each were measured for samples PHD1-6, and six aliquots were measured for GWD1-2 and TRG1-2. Mean De values with $1 \sigma$ standard uncertainty were used to determine the ages of the samples, except for GWD1-2, whose De values are in saturation. For these two samples, the minimum ages were calculated using 2 times characteristic saturation dose (D0) obtained from the dose response curve. To test the validity of the applied pIRIR protocol, a dose recovery test was performed. Six aliquots each for PHD1-6 were bleached for 4 hours in a solar simulator (Hönle SOL2). Three aliquots per sample were given a laboratory beta dose of $250 \mathrm{~Gy}$ and we tested if this laboratory dose could be accurately determined. The residual dose originated from the remaining pIRIR signal after the 4 hour bleaching was subtracted from the recovered dose. The dose recovery ratio has a tendency to overestimation of the given dose, however, they are all consistent with the acceptable range (0.9-1.1 Gy) within $2 \sigma$ uncertainty.

\section{GEOLOGICAL SETTING}

The Bay of Brest forms the boundary between two Variscan domains of the Armorican massif, the Leon domain to the north and the Central Armorican domain to the south (Fig. 1A) (Ballèvre et al., 2009). Crozon Peninsula is located to the south of the Bay of Brest and is affected by a low-grade brittle deformation with folding and faulting, along several main tectonic structures, mostly inherited from the Devonian Variscan orogeny and reactivated during the Eocene Pyrenean orogeny, the Oligocene rifting phase, and lately the Miocene -Alpine orogeny (Ziegler and Dézes, 2006; Anell et al., 2009). The later tectonic phase mostly occurred from the Langhian-Serravalian to the late Messinian under a N150 ${ }^{\circ} \mathrm{E}-$ trending shortening axis (Bergerat, 1987), and produced vertical motions of W-E elongated blocks (Le Roy et al., 2011). Further vertical motion of the Crozon Peninsula did not occur during the Plio-Quaternary, as proven by an Upper Miocene low stand platform preserved in several places close to the present-day sea-level, at Porz Kubu (Fig. 1B) Le Rhys, close to Douarnenez (Van Vliet-Lanoë et al., 2002), and at Pénestin (Vilaine river estuary; Van Vliet-Lanoë et al., 2009) (Fig. 2) The morphology of the Crozon Peninsula mainly results from Late Hercynian pedimentation (Triassic, $\sim 250 \mathrm{Ma}$ ), further re-shaped by successive marine transgressions, from the Early Jurassic (203 Ma) to Late Cretaceous ( 65 Ma; e.g., Bessin et al., 2015). The intense weathering of emerged Brittany, which occurred during most of the Cretaceous and Paleogene, provided up to $30 \mathrm{~m}$ of argillaceous saprolite (Wyns, 1991) preserved in basement compartments down-warped by Cenozoic inversion tectonics.

The study zone is located north of the main active structure of the region, the South Amorican shear zone (SASZ, Fig. 1b). The two main brittle faults around the Crozon Peninsula are the right-lateral $145^{\circ}$ trending Kerforne and the left-lateral $070-045^{\circ}$ trending Elorn fault systems that branches eastward to the North Armorican Shear Zone (NASZ) (Darboux et al., 2010; Le Gall et al., 2014; Plusquellec et al., 1999; Figs 1 and 2). The morphology of the Bay of Brest outlet (also called the Goulet) is largely controlled by these faults. 
Table 2: New IRSL dating

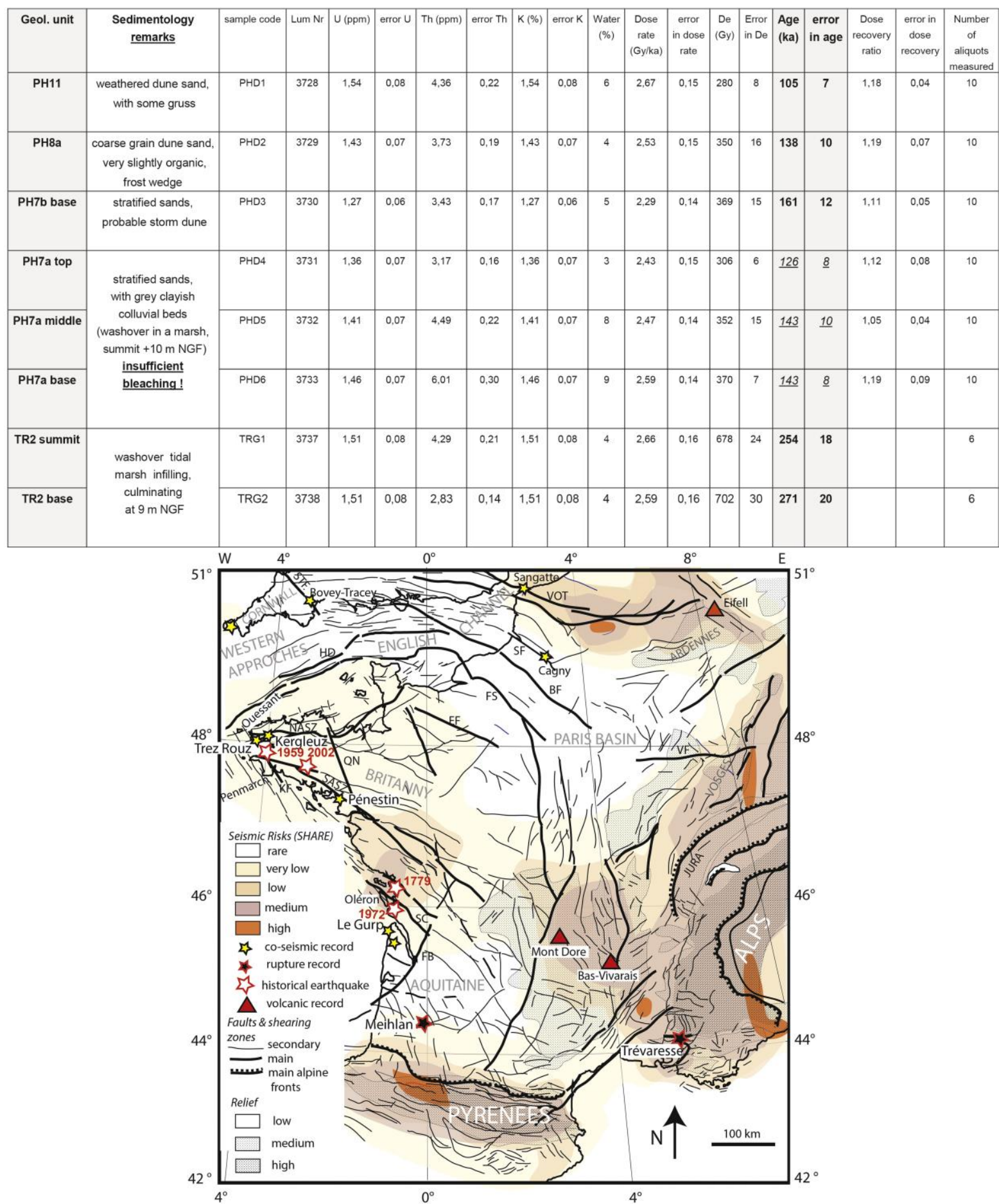

Figure 2. (color online) Map of the main superficial and subsurface faults and shearing zones compiled by the French Bureau de recherches géologiques et minières (1/1,000,000; https://www.geoportail.gouv.fr/donnees/cartes-geologiques) and the British Geological Survey. Details for Aquitaine: Rolet (1997) and Gély and Sztràkos (2000); details for northwestern France and Belgium: Mansy et al.(2003). Official seismic risks map compiled by Giardini et al. (2013; European Seismic Hazard Map [ESHM], Seismic Hazard Harmonization in Europe [SHARE] program]). BF, Bray Fault; EF, Eure Fault; FB, Bordeaux Fault; FS, Seine Fault; HD, Hurd Deep; KF, Kerforne Fault; NASZ, North Armorican Shear Zone; QN, QuessoyNort sur Erdre Fault; SASZ, South Armorican Shear Zone; SC,Saintes-Cognac graben; SF, Somme Fault; STF, Sticklepath Fault; VF, Vittel Fault; VOT, Variscan overthrust. 


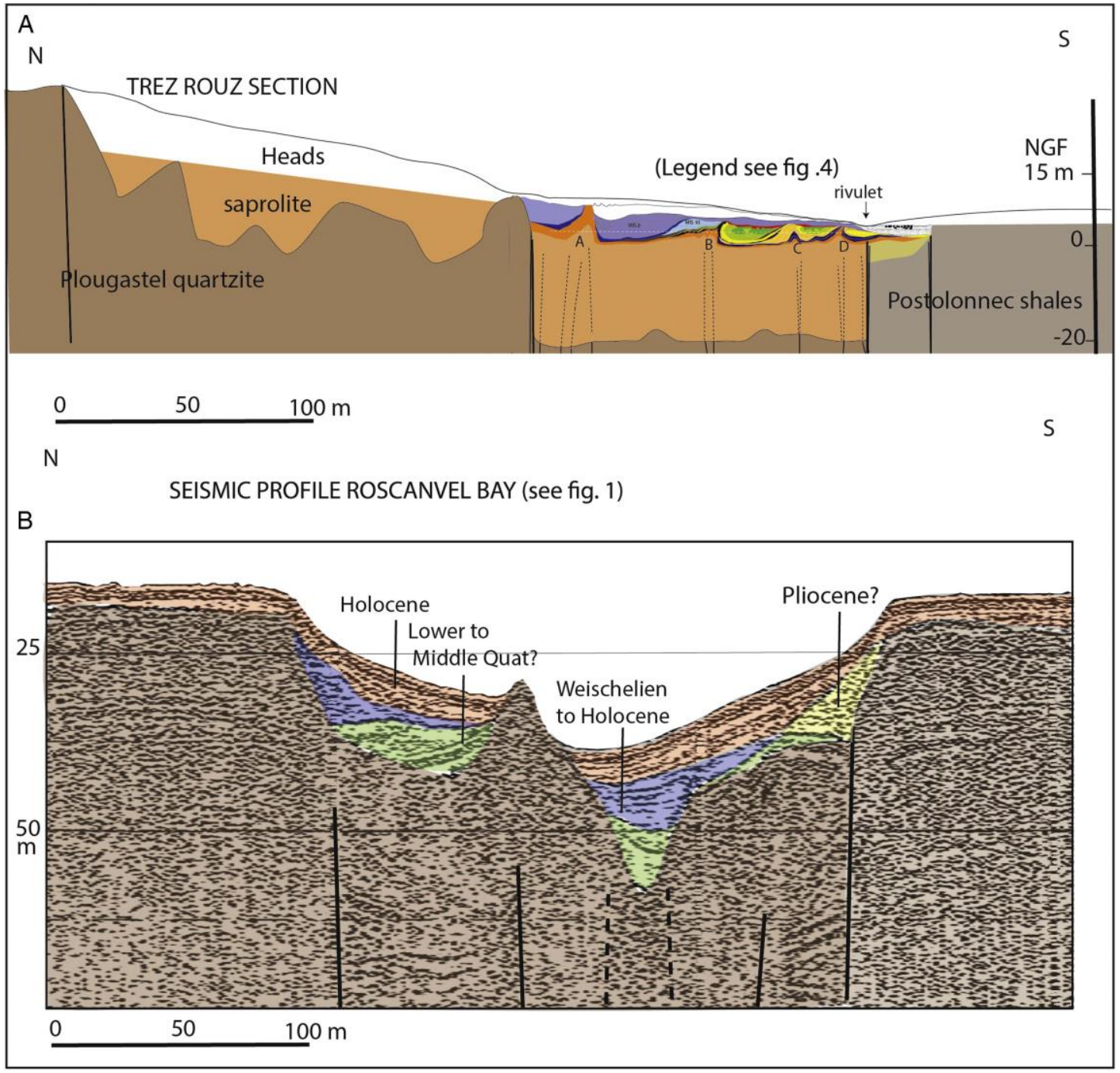

Figure 3. (color online) Trez Rouz graben geologic section with saprolite depth at scale (A) and a comparable Sparker seismic profile no.P4450, on its prolongation in the Bay of Roscanvel (B). Stippled lines below structures A to D in the upper diagram correspond to probable water-supplying faults preserved into the saprolite.

The opening of the Bay of Brest occurred after the lower Oligocene (lower Rupelian; Hallégouët et al., 1976). The collapse of regional deep weathered blocks of basement, well-marked in the topography and visible in the digital elevation model (DEM; Fig. 1B-C) allowed for the further excavation of the Goulet during the Neogene and Quaternary transgressive-regressive repetitive marine stages, especially by tidal scouring at the entrance of the bay. The Goulet embayment flooded at least after the Middle Miocene since coastal Langhian faluns have been discovered on the peri-Armorican shelf off Ouessant Island and the Penmarch Peninsula (Andreieff et al., 1972), to the west of the Bay of Brest (Fig. 2). The oldest deposits in the Elorn estuary are Lower Pliocene (lower Zanclean, Za1, 4.8 Ma), and suggest a limited opening of the Bay (tidal clays) during this period. A landward transgression followed and allowed the deposition of a stratigraphic sequence constituted by poorly preserved Piacenzian units, Gelasian units dated at $2.4 \pm 0.3$ Ma by ESR methods, and finally the Tiglian muds (Darboux et al., 2010; Van Vliet-Lanoë et al., 2002). From the Gelasian onwards, the sea level globally lowered. South of the Bay of Brest, the graben of Trez Rouz was flooded during most of the Pliocene (Chauris et al., 1980) (Fig. 1B). 


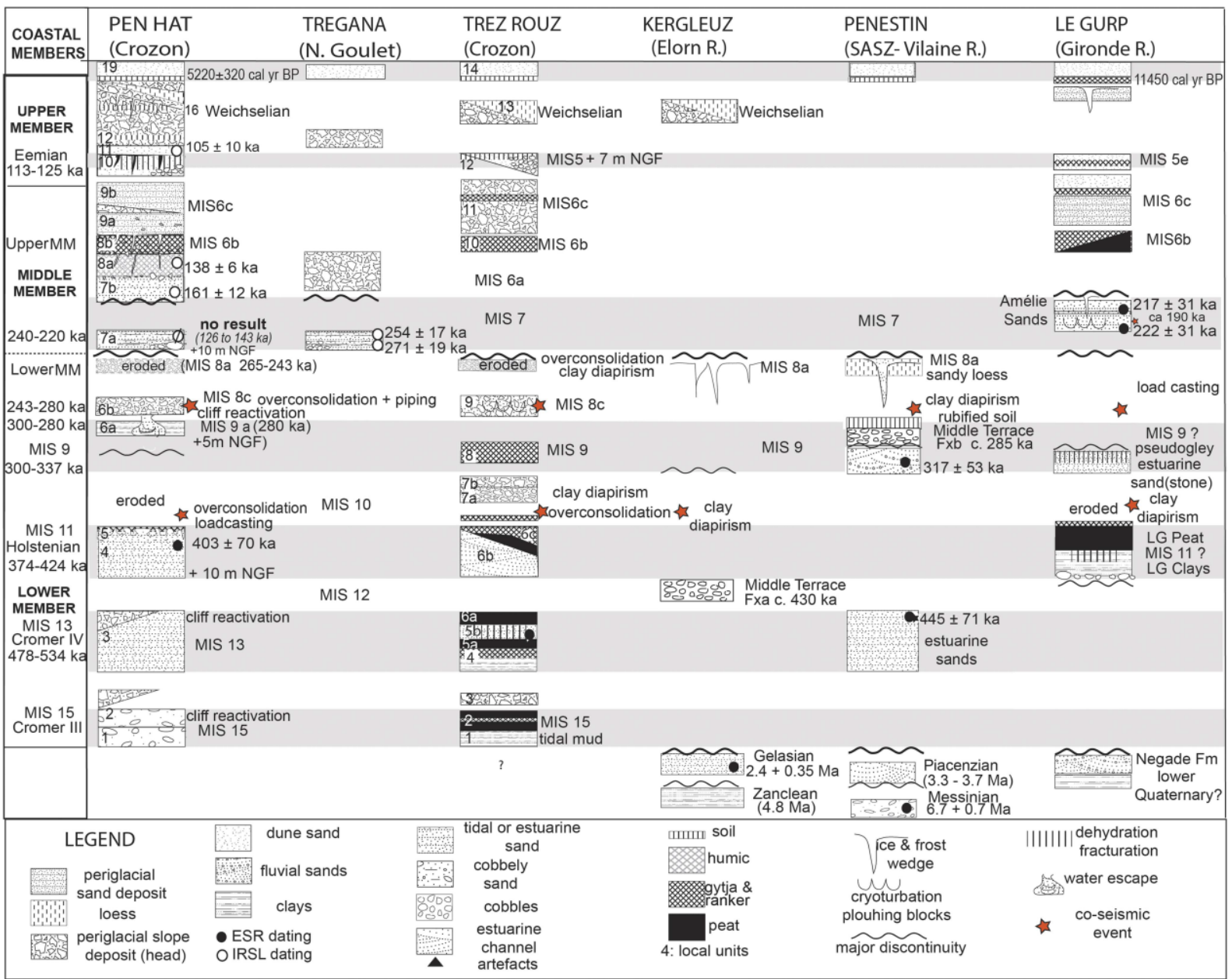

Figure 4. (color online) Relative chronology for the study sites, with the stratigraphic position of the coseismic and periglacial deformations. Ages between brackets are estimated. The stratigraphy for the Gurp section follows O'Brien and Jones (2003) and Sitzia et al (2015). Those of Pénestin are extracted from Van Vliet-Lanoë et al. (1997) and Van Vliet-Lanoë et al. (2009). ESR, electron spin resonance; IRSL, infrared-stimulated luminescence; MIS, Marine Oxygen Isotope Stage; $N G F$, French Ordnance Survey (5m NGFcorresponding to above sea level); SASZ, South Amorican Shear Zone.

\section{SEISMIC SETTING}

Currently, a number of Variscan structures are seismically active faults that could be assigned to the far stress field produced by the Africa-Eurasia convergence and the mid-Atlantic ridge push, with a NW-SE compressional stress and a NE-SW extensional stress deduced from numerical modeling analyses (Golke and Coblentz, 1996) and GPS and seismological studies (Nocquet et al., 2012; Perrot at al. 2005; Mazabraud et al., 2005). The stress field is mainly strike slip with an extensional component attributed either to the buoyancy forces arising since the last deglaciation and explaining the general apparent uplift in Brittany (Bonnet et al., 2000) or to local variations in rheology favoring stress perturbation (Mazabraud et al., 2013).

The seismicity around the Bay of Brest is significant, with several low magnitude earthquakes (Arroucau, 2006; Haugmard, 2017) with magnitudes between $1.6 \leq \mathrm{M}_{\mathrm{w}} \leq 3.2$ and within a range of depth from 2 to $25 \mathrm{~km}$, following the SI-Hex catalog from 1965 to 2009 (Cara et al. 2015). However, the seismicity in the western part of France shows an occurrence of moderate earthquakes with $\mathrm{M}_{\mathrm{w}} \geq 4$, such as the Hennebont earthquake in 2002, $\mathrm{M}_{\mathrm{w}}$ 4.3, along the SASZ (Perrot et al., 2005). During the instrumental period (since 1965), only one stronger earthquake occurred, with $\mathrm{M}_{\mathrm{w}} 5.0$ occurred close to La Rochelle (Cara et al. 2015) in 1972. 
The historical seismicity presents a similar pattern along the Atlantic margin of France, with 61 events of $4>\mathrm{M}_{\mathrm{w}}>5$, and 7 with $\mathrm{M}_{\mathrm{w}} \geq 5$ between 1286 and 1959 (FCAT-17 catalog, Manchuel et al., 2017). Four of them are located in the Vendée and La Rochelle area including one of the biggest historical events, the $\mathrm{M}_{\mathrm{w}} 6.3$ Bouin earthquake that occurred in the Marais Breton in 1799 (Manchuel et al., 2017). Two other events occurred close to Meucon (1286 and 1930) and one $M_{w} 5.4$ event occurred near Quimper in 1959 probably along the SASZ (Manchuel et al. 2017). Our study sites are located $55 \mathrm{~km}$ from Quimper, 105-115 km from Hennebont, and at a minimum distance of $25-40 \mathrm{~km}$ from the SASZ.

\section{DATA}

\section{Trez Rouz}

The key-section, Trez Rouz, is located on the Roscanvel peninsula of Crozon (Figs. 1B and 5) at the entrance of a SW-NE trending shallow depression linking the Bay of Brest to the Atlantic Ocean. The formations that outcrop along the coast $(\mathrm{N} 48.30513920055813 \quad$ W-4.571393482757003) are located at the western termination of a $060^{\circ}$-trending graben, which is bound by satellite faults of the $060^{\circ}$ trending Elorn fault system. The site is also under the influence of several branches of the $150-160^{\circ}$ trending Kerforne fault system (Fig. 1B). Indeed, NW-SE-trending faulting has been observed into Paleozoic shale that mostly crop out at the southern end of the beach. This graben preserves 20-25 m of saprolite and supposed Pliocene sandy gravel deposits (Chauris et al., 1980). The overall geometry of the graben infill seems rather similar to the observation extracted from a Seismic Sparker profile located east of the site. This profile shows the structures extending the graben onshore to the east in the Roscanvel Bay, partly affected by a flooded river incision, with possible Pliocene relic sedimentary bodies (Fig. 3).

The NW side of the Trez-Rouz graben (Figs. 3 and 5) is shaped by at least two erosional surfaces. The highest one is perched around $15 \mathrm{~m} \mathrm{NGF}$, to the north, and affects the faulted and weathered sandstones constituting the Pointe du Pouldu, located in the graben (Fig. 3). Following the clay mineralogy of the sediments (Melou, 1968), the Pointe du Pouldu corresponds to the feeding zone of most of the periglacial slope deposits in the main section. These deposits are rich in kaolinite and sandstone clasts (TRZ 9). The southern part of the graben is occupied by $\sim 2 \mathrm{~m}$ of Quaternary sediments lying on a much more shallow basement $(5 \mathrm{~m}$ close to the rivulet, black arrow in Fig. 5A, emerging at $\sim 50 \mathrm{~m}$ to the south of the river). The second erosional surface corresponds to a flat surface that truncates the shale, and can be interpreted as a raised platform at $7 \mathrm{~m} \mathrm{NGF}$, related to the last raised beach (possibly Eemian, MIS 5; Fig. 5E).

Stratigraphic record (Figs. 4 and 5-2):

Periglacial deposits are commonly labeled "heads" in Western France and the United Kingdom. Their description has been completed from Van Vliet-Lanoë et al. (1997) for the TRZ1 to TRZ3 deposits (Fig. 5). New observations have shown a succession of 4 main upward dissymmetric injections or folds (A-B-C-D; Fig. 5), from north to south. The units include:

TRZ1: Tidal mud, stratified and faulted. Only visible in the southernmost major injections (D) (Fig.5D).

TRZ2: Lower peat complex: It consists of two levels of black peat separated by a gyttja layer, and includes large fragmented wood remains.

TRZ3: Beige clayey loam, including angular clasts of quartz and unweathered shale. This unit is derived from the local saprolite (Mélou, 1968) and is faulted by $060-070^{\circ}$ trending fractures spaced about $70 \mathrm{~cm}$ apart, with vertically injected clasts of quartz and shales concentrated in structure B (Fig. 5B).

TRZ4-6: Main peat complex (Figs. 5-2). Above this unit, most of the deposits are derived from the weathered 
Landevenec sandstone to the north (Mélou 1968). It is the sequence studied by Morzadec (1974) and Field et al., (2010).

TRZ4a: Bleached clayey loam, faintly stratified, laterally linked to an organic gyttja type accumulation, truncated by a stone line and is faulted by 060-070 trending fractures spaced about $70 \mathrm{~cm}$ apart (Fig. 5E).

TRZ4b: Dark grey organic loamy clay.

TRZ5a: Peat, homogenous, dark brown, evolving in a water-laid accumulation of wood and bark fragments (conifers, alder, birch, shrubs, ferns), often in a vertical position (injection).

TRZ5b: Humic sand: sandy schorre soil evolving laterally into a tidal channel.

TRZ6a: Peaty loam, rich in wood fragments and seeds (Potamogeton), richer in intraclasts to the top; partly fragmented to the top.

TRZ6 b: Stratified alternation of silty sand and gravels, supported by a silty matrix, corresponding to a tidal channel to the south of the main structure B (Fig. 5B). It partly overlaps structure B and is slumped.

TRZ6c: Humic bleached loam reworking sand and quartz gravel and onlapping TRZ6a and TRZ6b. To the south, a thick peat complex is preserved at its base.

TRZ7 -TRZ8: Lower head complex sloping to the north:

TRZ7: Consists of a series of two heads, including several weakly developed hydromorphic palaeosoils, and ends with very coarse clasts of shale and quartz. At the top of structure B, the upper layer presents gravels in stacking (slump) with fragmented organic remains, resulting in the bulging of structure B. On the southern side of the main deformation, between the two most important injections, the TRZ7 layer is over-thickened and almost horizontal at its base; it consists of a $1 \mathrm{~m}$ - thick deformed aggradation of sandy to gravely series including more loamy layers, somewhat organic, with rare wood fragments. It seems to correspond to a dell infilling.

TRZ8: Consists of a humic loam, interstratified sandy loamy heads deformed by periglacial ploughing blocks (Fig. 6B), with some coarse clean sand at the base and it corresponds to a gyttja. A thick gley complex buried this layer.

TRZ9-10: This is a second sequence of heads, partly reworking dune sand and humic material, buried under bleached heads, including large clasts. TRZ10, a clayey loamy head is rubified by pseudogley palaeosoil on reworked saprolite.

TRZ11-13: Upper sequence of yellowish heads, mostly loamy. It includes a brown podsolic palaeosol at its base that evolves to the south of the rivulet into a raised cobble beach (TRZ12) including stony patterned ground to the north. These heads truncate the whole sequence with a slope toward the south.

\section{Palaeoenvironmental reconstruction of the main peat complex at Trez Rouz}

The presence of Azolla filiculoides (Morzadec-Kerfourn 1974) indicates a pre-Eemian age for the Main Peat Complex (TRZ4-6). Peat layers are formed under mild temperate oceanic conditions with thermophilous aquatic plants, indicating deposition during interglacial periods. The absence of Tertiary pollen discounts an early Pleistocene age (last occurrence or LADs) and is thus mid- Pleistocene. This peat was first attributed by palynological studies to the Holsteinian (MIS 11; Morzadec-Kerfourn 1974; Van Vliet-Lanoë et al, 1997; Field et al., 2000; Morzadec-Kerfourn, 1999). The sandy layer, TRZ5b, intercalated within the peat complex has been dated to $470 \pm 53$ ka by ESR methods (MIS 13; Van Vliet-Lanoë et al., 2000). Several interglacial stages that had slightly higher sea levels than today (MIS 9, MIS 11, MIS 13, MIS 15; Rohling et al., 2009) have similar palynological characteristics (Scourse et al., 2009). The plant macrofossil assemblage does not contain any biostratigraphic markers that allow for a specific interglacial stage determination.

TRZ4-5a corresponds to a marshy area partly submerged under a slightly brackish, shallow water-body with both woodland (Quercus, Corylus, Fraxinus, Ilex aquifolium), waterside, and damp ground habitats (Alnus glutinosa, Osmunda regalis in TRZ5a) present on the surrounding slopes. After this humiferous clayey sand deposition, poor in plant macrofossils, the dated TRZ5b clayey sand were deposited within the marsh, probably associated with a slight cooling and storminess. This may be related to the opening of a coastal ridge or most likely to the colluvial infill by dune sand mixed with clayey slopewash, isolating the depression.

TRZ6a peat corresponds to a renewed shallow brackish lagoon with Caulinia goretskyi, Potamogeton occidentalis, and Ruppia maritima, possibly tracing another highstand in a forested landscape. The absence of 
both reed-swamp and damp woodland in the site suggests a narrow depression with some spring seepage, with most of the local saprolite being eroded. The presence of Vitis and Buxus in TRZ6a suggests rather mild conditions, initially warmer than TRZ4-5, followed by the onset of limited climate cooling. These conditions can be correlated with the Cromerian Interglacial IV recorded as MIS 13 in the Netherlands (Zagwijn, 1996). As the ESR dating gives a maximum age of $523 \mathrm{ka}$, the whole main complex might fit either with MIS 13a, or MIS13c. It is thus covering the thermal spike of MIS 13a ( 490 ka; Railsback et al., 2015). The entire main peat complex (TRZ4-5a) should fit MIS 13a to the MIS 13 eustatic maximum (MIS 13c). More precisely, TRZ4-5a might fit the MIS $13 \mathrm{c}(\sim 525 \mathrm{ka})$ because palynology indicates in this unit an ongoing transgression (Fig. 4).

TRZ6c could correspond to the classic Holsteinian time (MIS 11, Koutsodendris et al., 2010), which is longer and warmer than MIS 13. The unit is associated with TRZ6b, which represents a shallow tidal channel, probably initially $25 \mathrm{~m}$ wide, with a lateral peaty salt marsh (Fig. 7 phase I). Units TRZ1 and TRZ2 should correspond to interglacial highstands older than MIS 13, probably the complex MIS 15, with 3 highstands (MIS 15e, 15c, and 15 a; Cromerian III Interglacial: Railsback et al., 2015). They represent the closing of a tidal channel and two episodes of brackish peat formation (TRZ2) separated by a gyttja.

The last humic layer, TRZ10 consists of lacustrine organic sediment deposited near the shore. TRZ10 was considered as an upper interglacial stage by Morzadec-Kerfourn (1974) presenting "cold-temperate" vegetation (Corylus, despite presence of Ilex) in the lower part and a late temperate period in the upper part. The unit could correspond to part of the MIS 7, as TRZ12 is clearly connected to the south with the last raised beach (MIS 5). The presence of a thin loess cover at the top of TRZ13 heads (Fig. 5E), with periglacial patterned ground, suggests that the whole sequence is older than Eemian (MIS 5). Below, the pseudo-gley soil (TRZ10) is rubified, partly inherited from the Landevennec sandstone, which is related to some seasonal hydromorphism, consistent with the morphology. This unit may have form during MIS 7 or earlier.

The remaining organic soil, the base of TRZ8, should, by deduction, correspond to a MIS 9 palaeosol stretched by solifluction. Unit TRZ9 is deposited by periglacial solifluction and colluviation, which implies available moisture and seasonal frost. The conditions favorable to these processes normally occurred during early glacial conditions, when the sea level was not too low and the climate was still oceanic (with the presence of snow). This unit could be correlated with MIS 8c. The injection of structure A occurred early during this substage, because jarosite, a sulphate complex inherited from the bacterial degradation of pyrite issued from brackish or marine waters, is present in the structure.

\section{Structures and deformation}

Four main structures are considered here, from north to south A-B-C-D, forming upward dissymmetric hydroplastic injections, oriented $060^{\circ}$ (Figs. 5, 6A, and 8).

The northernmost structure A is the largest ( $5 \mathrm{~m}$-wide). This structure vertically deforms the unit TRZ8 and is present exclusively in saprolites. The $\mathrm{B}, \mathrm{C}$, and $\mathrm{D}$ structures are thin $(<2 \mathrm{~m}$-wide). They are mostly tilted to the SW, in conformity with the present-day slope. They rework several generations of peats (MIS 11: TRZ 6; 13: TRZ 5; 15: TRZ2). Deformation B is the most spectacular and affects the dated sandy layer (TRZ 5b). Structure $\mathrm{C}$ reworks the two oldest peats and is cored by a third peat. Structure D only reworks the two older peat units (TRZ2) and is injected by stratified clays (Fig. 5D, TRZ1). Some small sandy liquefaction features occurred within fold B in association with the brecciation of the lower part (TRZ5a, Figs. 7B, red star, and 8-1). Similar brecciation deformed the upper part of the injected peat structure C. In TRZ4, quartz vein clasts are vertically oriented but in a step-like stacked succession as in an injection (Fig. 5A). Fragments of roots are mostly still in connected positions in the TRZ6a peat. None of the ligneous remains are intact in the TRZ5a and TRZ2 peats and most of them are fractured wood and bark fragments and dispersed throughout the entire sediment. These suggest flotation and liquefaction. Many wood fragments were reworked with oriented clasts in unit TRZ6c, attesting to mudflow and erosion of the main peat injection. One of the deformation features occurred in the upper part of TRZ6c when the water-table level was still high (floated fragments). Some larger deformations clearly suggest fold shortening between injection folds B and C (Fig. 5, unit TRZ 7) and to the south of structure A. A set of fissures, mostly parallel and vertical, affects most of the upward injected features (structures A, B, C, and D; Figs. 5 and 8-2). The fissures trend $060^{\circ}$ parallel to the length of the graben and to the direction of major faults in the Paleozoic basement that crops out on the northern side of the graben (Figs. 5-2 and diagram in Figs. 
$8-2)$.
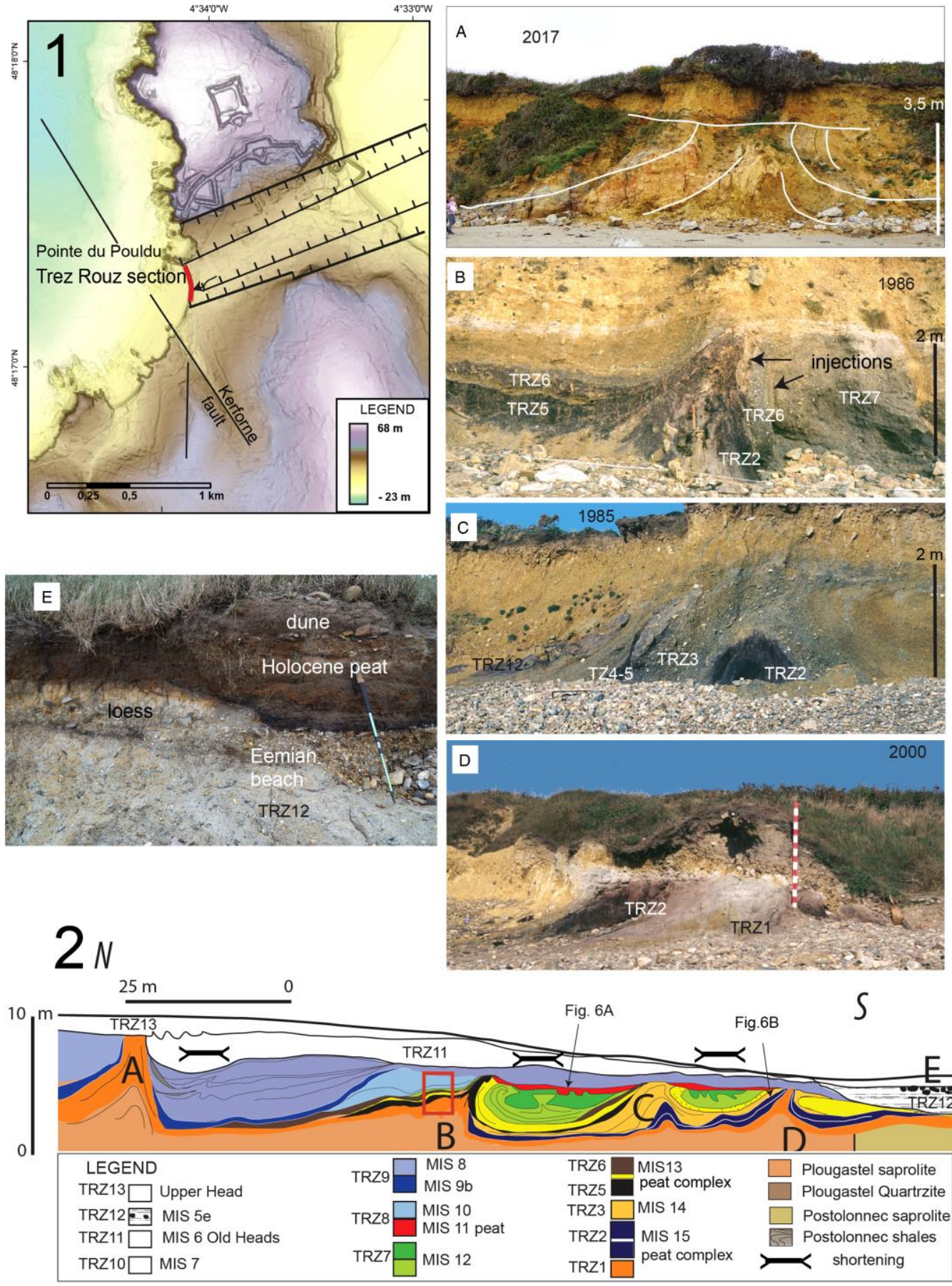

Figure 5. Trez Rouz sites. (1) Location of the Trez Rouz section (in red) on the high-resolution digital elevation model. (2) Log of thesection and detail of the section structures $A, B, C, D$, and E. Black arrow: rivulet. Note the shortening deformation figures of the unitsTRZ9 and TRZ7. The red square corresponds to the section investigated for plant macrofossil assemblage and palynology.

Horizontal microstructures that look like slickensides are present on some fissure planes. They are similar to slickensides on basement faults that trend $060^{\circ}$ (Fig. 3). Such slickensides are common in clayey soils after desiccation (Irfan, 1996), but here they are likely oriented following the local stress field. This deformation is contemporaneous with a general consolidation of the fissured units. At a smaller scale, the injected masses in 
fold $\mathrm{B}$ are affected at the same time by antithetic micro-fracturation, dipping at $90^{\circ}$ in the TRZ4 organic layer, with scale-like normal successive collapses and in a form of $20^{\circ}$ dipping microshear planes in the stretched loamy sand (TRZ5b; Figs. 8-2 C-D). These deformation structures do not affect unit TRZ6a. They seem related to substratum retraction, fissuring, and consolidation by drainage and desiccation. These microfaults in the peat are underlined by jarosite.

Structure D is located at the crossing of two injection trending 150 and $060^{\circ}$ with lateral injection blisters (Fig. 6A). These two directions correspond to those of the Kerforne fault system and the Elorn fault system, respectively. These two fault systems join at the Trez Rouz site (Fig. 1B). Periglacial deformations end the record of each set of units including frost creep bending and ploughing blocks (Fig. 6B).
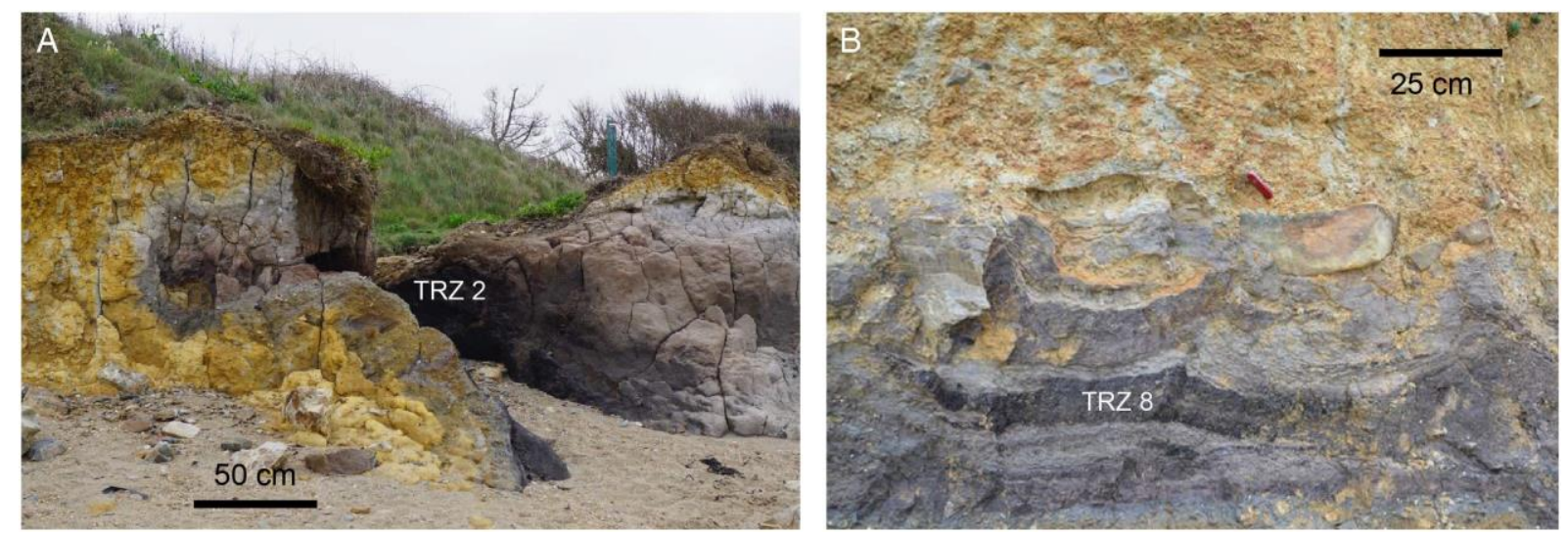

Figure 6. (A) Lateral injection in structure D, deforming unit TRZ2 (observation 2017). (B) Ploughing (soliflucted) block involutions between structures B and C, unit TRZ10; deforming TRZ8 organic soil (2004).

\section{Sequence of deformation events}

Retro-deformation analysis allowed us to restore stratigraphic units to their original geometries and to recognize several seismic events (Fig. 8, phase I). From MIS 15 to MIS12, a succession of fluvial and coastal units (TRZ1 to TRZ7) incised the thick saprolite preserved in the graben (phase I, Fig. 7). The first main deformation occurred from the end of TRZ6c deposition, probably at the time of the transition between MIS 11 and the onset of the MIS 10 cooling event, ca $380 \mathrm{ka}$ (phase II, Fig. 7). This deformation is associated with the formation of the B, C, and D structures, further bent by solifluction. After that, periglacial slope deposits partly filled the depression between the uplifted zone and the northern border fault (phase III, Fig. 7). The next seismic event is attributed to structure A, which is younger than most of the TRZ9 unit (phase IV, Fig. 7). This event produces only local retraction fissures, the other structures being (TRZ1 to TRZ6) now consolidated. An early MIS 8c age could be attributed to the event that deformed the TRZ9 unit. The deformation is possible due to the presence of marine water that impregnated the saprolite (jarosite), indicating that the sea level was still high despite the periglacial colluvial nature of TRZ9. This may also be the result of a persisting high sea level or saturation by seismic pumping from a shallow marine water wedge (Figs. 3 and 7). In addition, periglacial solifluction was still active, regulating the northern side of the graben in two steps separated by palaeosols (phases V and VI). 

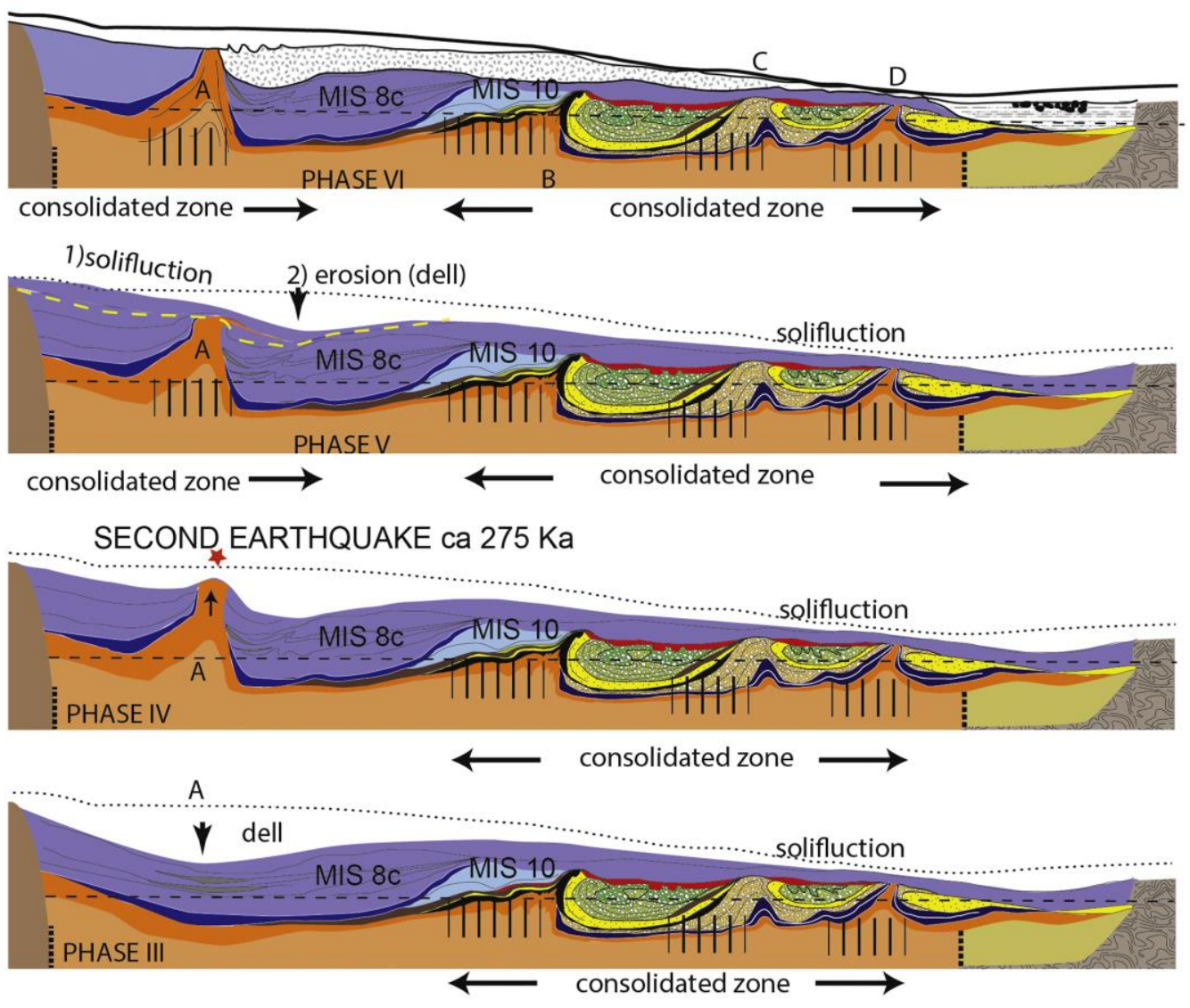

MAIN EARTHQUAKE ca $380 \mathrm{Ka}$

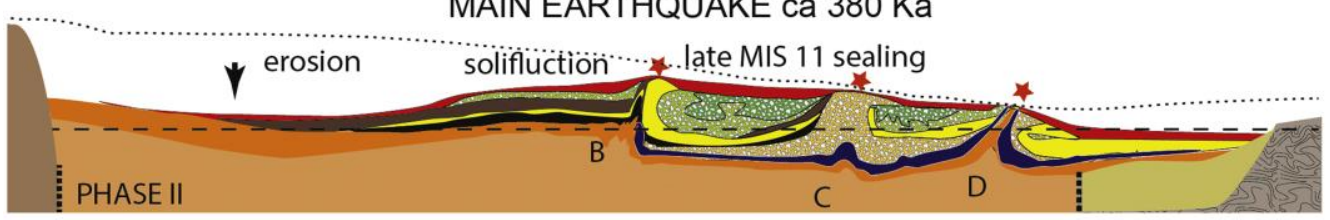

Initial situation ca $430 \mathrm{ka}$ (MIS 12)

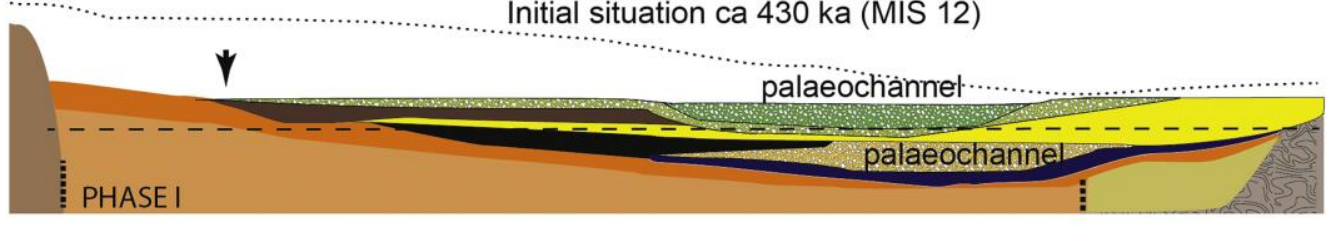

\begin{tabular}{|c|c|c|}
\hline LEGEND & & $25 \mathrm{~m}$ \\
\hline $\begin{array}{l}\text { TRZ13 } \square \text { Upper Head } \\
\text { TRZ12 } ⿴ \text { MIS 5e }\end{array}$ & $\begin{array}{l}\text { TRZ7 Fluviatile } \\
\text { MIS12 }\end{array}$ & |||||| $\begin{array}{l}\text { dehydration and } \\
\text { prismation/fissuration }\end{array}$ \\
\hline $\begin{array}{l}\text { TRZ11 } \text { Old Heads MIS } 6 \\
\text { TRZ10 } \square \text { MIS } 7\end{array}$ & $\begin{array}{l}\text { TRZ6 } \\
\text { TRZ5 } \\
\text { peat complex }\end{array}$ & $\begin{array}{l}---\quad 7 \mathrm{~m} \mathrm{NGF} \\
\ldots . . . \\
\text { boundary faults }\end{array} 10$ \\
\hline $\begin{array}{cl} & \text { MIS 8a (very cold, arid) } \\
\text { TRZ9 } & \text { MIS 8c (cold, humid) } \\
& \text { MIS 9b } \\
& \text { MIS 10 } \\
\text { TRZ8 } & \text { late MIS11 }\end{array}$ & $\begin{array}{l}\text { TRZ3 } \square \text { Fluviatile } \\
\text { MIS } 14 \\
\text { TRZ2—MIS } 15 \\
\text { TRZ1 peat complex }\end{array}$ & $\begin{array}{l}\square \text { Plougastel saprolite } \\
\square \text { Plougastel Quartrzite } \\
\square \text { Postolonnec saprolite } \\
\text { Postolonnec shales }\end{array}$ \\
\hline
\end{tabular}

Figure 7. Reconstitution of different phases of deformation of the Trez Rouz section. Red stars stand for injection. MISMarine Oxygen Isotope Stage; NGF-French Ordnance Survey (5m NGF corresponding to above sea level). 

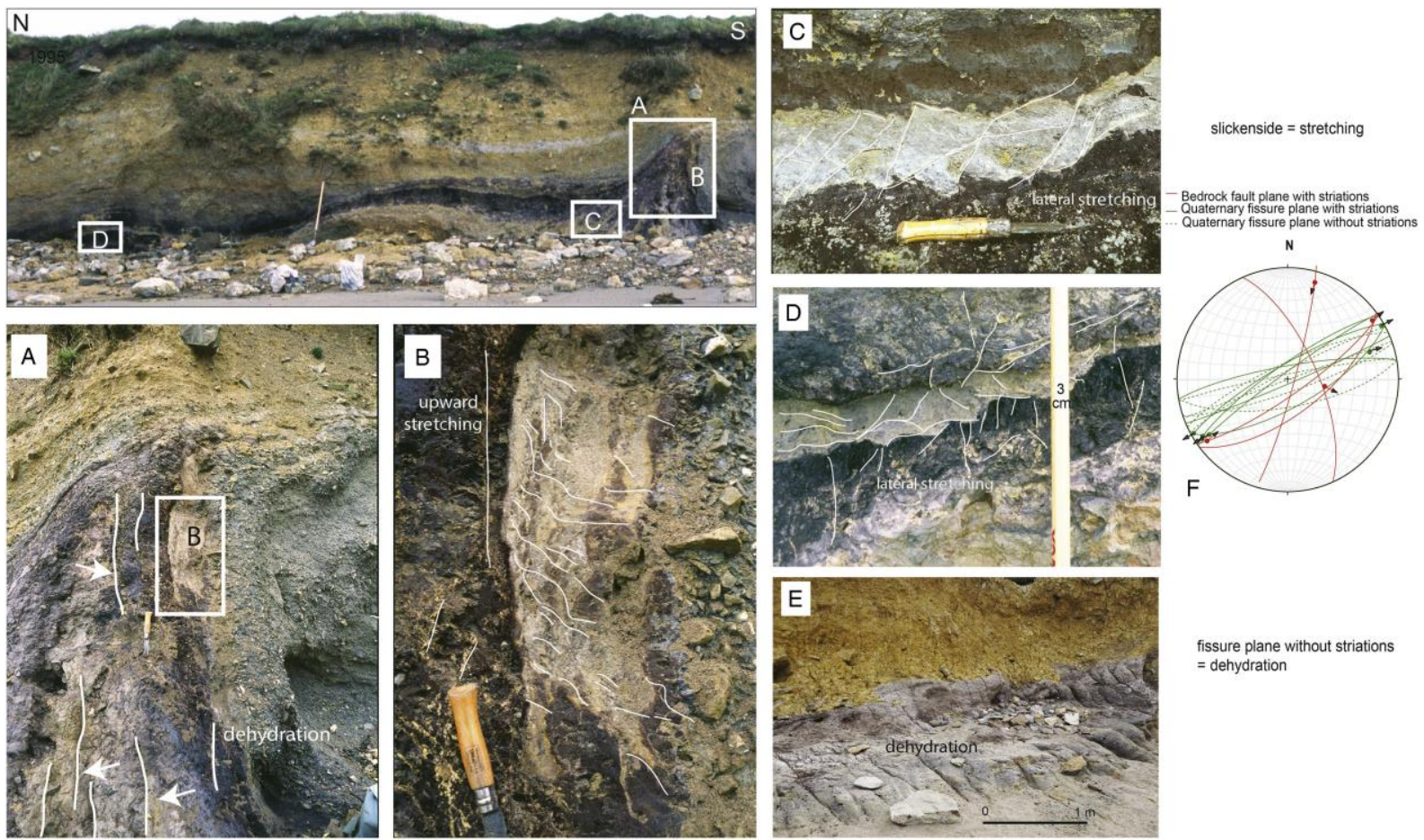

Figure 8. Details of sites 8-1 and 8-2. Structure B details (Fig. 5). (A and B) Site 8-1 showing main injection, liquefaction (red stars in Fig. 7) retimed by stretching fissuring (slickensides in white), $C$-D to the north and B to the south; notice dehydration fissures below the injection in A. Site 8-2 showing stretching (stretching fissure) (C) and fissuration (retraction) (D) related to the dehydration of the liquefied saprolite. (E) Simple fissuring by dehydration, north of structure C. Notice the antithetical character of the stretching fissures on each side of the injection: $C-D$ to the north and $B$ to the south. The diagram plots the orientation of the basement faults and the two types of fissuration in the sediment. (F) Fault planes and associated slickenside (black arrows).

\section{Pen Hat section}

The Pen Hat section is located (N 48.27672259941417; W-4.619458668303878) between the Toulinguet and Pen Hir Points (Figs. 4 and 9A). The two ridges are armored by Armorican sandstones, raised by an NE-SW trending faulted anticline leading to the outcrop of Brioverian quartz-rich shales. Pen Hat anticline is separated from the Trez Rouz graben by the Kerforne fault system (Fig. 1B). The Pen Hat section is located along a fossil cliff incised in the faulted quartz-rich shale at the contact with the sandstones (Fig. 9A). The bedrock was abraded by marine erosion and is partly buried by two series of Pleistocene deposits. A Holocene dune and a beach cobble ridge occupy the northern part of the bay. This section was completely independent of the Bay of Brest fluvial system during low stands (Hallégouët, 1994).

\section{Stratigraphy (Fig. 4):}

The most complete section is visible in the north-eastern part of the Pen Hat bay, at the foot of Toulinguet Point, with an approximately $20 \mathrm{~m}$ thick layer of Pleistocene formation. The upper levels crop out along the lower to central portion of the bay. The lower contact is highly weathered, and is thus the source of dark grey clayey saprolite from the quartz-rich shales. The base of the Pen Hat section (unit PH4) yielded an ESR age of $403 \pm 70$ ka or MIS 11 (Van Vliet-Lanoë et al., 2000).

The following units may be distinguished (Fig. 4):

PH1: marine cobbles and gravels in a silty (kaolinitic cristaline silt) sandy matrix, resting on a platform cut into quartz-rich shale, $\sim 5 \mathrm{~m} \mathrm{NGF}$. 
PH2: mixed marine pebbles and clasts in a loamy matrix. This unit corresponds to a shore deposit with shore ice rafting characteristics.

PH3: marine sands with some gravels. A lower palaeolithic industry is included, close to the foot of the palaeocliff.

PH4: hydromorphic "podsolic" sandy clayish palaeosol, buried by grey clayey sands with some sandstone and shales flakes. This sand yields an ESR age of $403 \pm 70 \mathrm{ka}$ BP (Van Vliet-Lanoë et al., 2000). This unit is interpreted as an oxidized organic gley in a salt marsh depression located between two beach ridges.

PH5: level of brownish sand deformed by load casts, consolidated.

Units PH4 and PH5 are locally pierced by hollows or pipes filled by marine sands with local concentrations of heavy minerals, with tubular stratified "marine" sand bodies infilling the hollow in PH4 (Fig. 9C). Pressure fracturing is marked at the base of the hollows. Some partly reworked archeological artifacts are preserved (Fig. 4).

PH6: dark grey stratified clayish mud including lateral heads, thinning to the south, strongly consolidated.

PH7a: stratified sand body interlayered with grey silty clay; it forms a storm built idal bar, invading a low marsh (washover fan) and evolving into beach on the top, at the contact of the $7 \mathrm{~m}$ platform (southern part of the section). Behind this ridge, a lagoon facies with developed tidal clayey layers and with some admixture of clasts toward the top is present. The ESR dating (Van Vliet-Lanoë et al, 2000) and the IRSL dating failed because there was too little initial bleaching of the clayey sandstone saprolite, with aberrant age between 126-143 ka. However, the basal stratified marine sands from the similar and nearby Trégana section (washover fan; $6 \mathrm{~km}$ to the North, on granite; see Figs. 1B and 4) provided IRSL ages of $254 \pm 18$ and $271 \pm 20$ ka (early MIS 7, see Table 2).

PH7b: aeolian sand including gravels and clasts in upper horizons, dropped from the overhanging cliff. The IRSL dating yields an age of $161 \pm 12 \mathrm{ka}$.

PH8a: aeolian sand, slightly humic and some frost-wedges in the southern part of the section. The IRSL dating yields an age of $138 \pm 10 \mathrm{ka}$.

PH 8b: humic podsolic soil developed in aeolian sand.

PH9: aeolian sand including some dropped clasts from the cliff.

PH10 to PH19 corresponds to the Upper Pleistocene heads following the Eemian (MIS5e) palaeosol. PH11 yields an IRSL age of $105 \pm 7 \mathrm{ka}$. They are connected with a cryoturbated beach in the central part of the bay. The Holocene dune sand, PH19, includes Pomatia elegans dated at $5220 \pm 320 \mathrm{cal}$ yr BP at its base.

\section{Interpretation}

The stratigraphic interpretation and correlations with the Trez Rouz units are given in Figures 4 and 10. We argue for seismic deformation produced the load casts in unit PH5 (Fig. 8C) and the erratic hollows filled by tubular bodies, themselves filled by stratified marine sands, with local concentrations of heavy minerals in PH4. These structures represent a water-escape, under pressure and confined upward by the overconsolidated stratified clay of unit PH6 (Fig. 9A-B-D). The existence of overconsolidation of the lower units at Pen Hat, of a level of load casts in unit PH 5, and of a younger oriented water escape features in unit PH4-5, confined in space by unit PH6, argue for a series of earthquakes. PH4 yielded an ESR age of $403 \pm 70 \mathrm{ka}$, suggesting the largest liquefaction events are younger, but older than PH7, a MIS 7a tidal complex (Fig. 4). The load cast event (PH5) is thus slightly younger than $403 \pm 70 \mathrm{ka}$. 

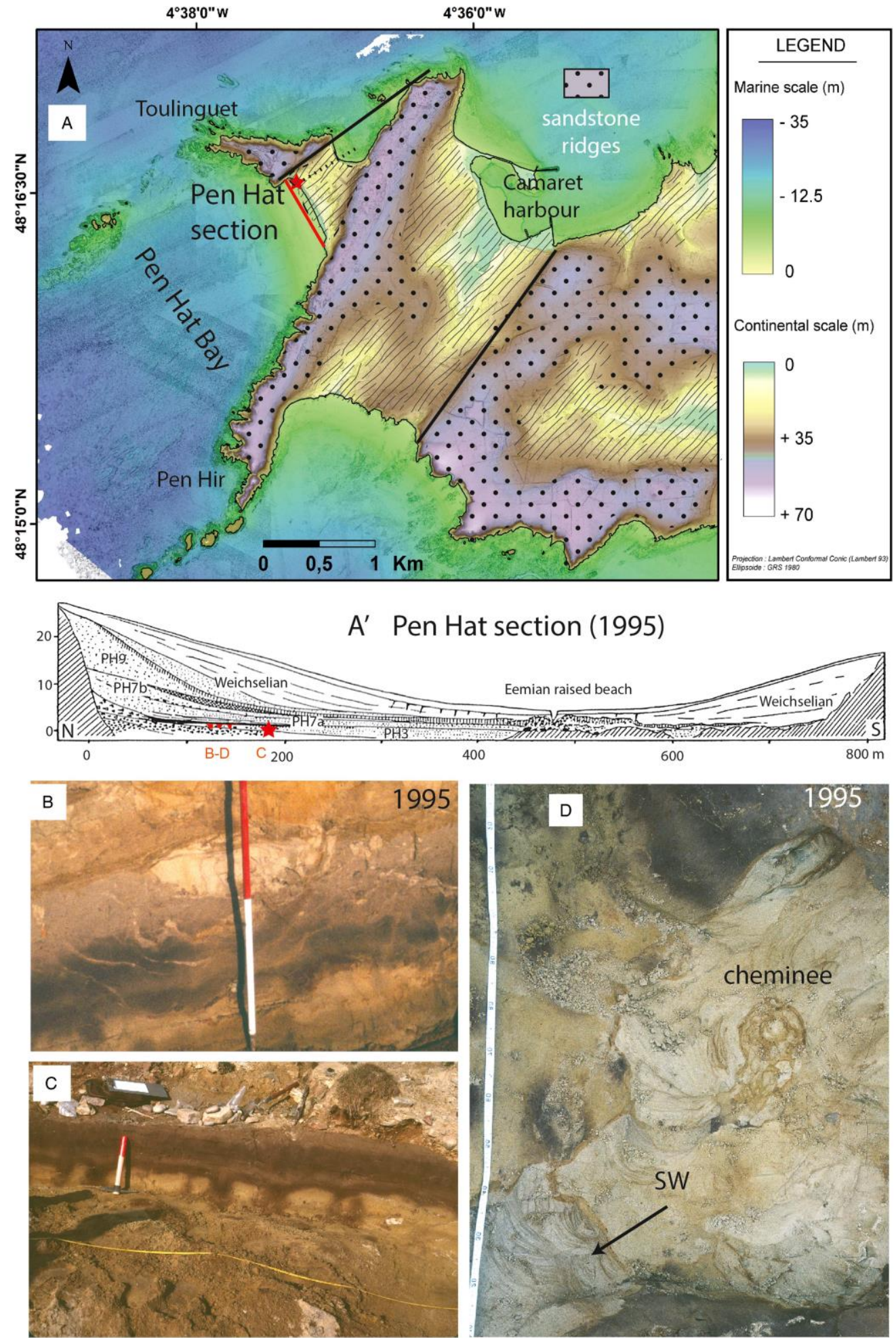

Figure 9. Pen Hat study site. (A and A') Location and global section. The deformation structures are located at the red star. (B) Water escape structures with fracturing related to its propagation (in unit PH5). (C) Load cast level affecting paleosol PH4. (D) Horizontal section in the largest water escape showing tube propagation to the southeast (in unit PH4).

\section{Interpretation}

The stratigraphic interpretation and correlations with the Trez Rouz units are given in Figures 4 and 10. We argue for seismic deformation produced the load casts in unit PH5 (Fig. 8C) and the erratic hollows filled by 
tubular bodies, themselves filled by stratified marine sands, with local concentrations of heavy minerals in PH4. These structures represent a water-escape, under pressure and confined upward by the overconsolidated stratified clay of unit PH6 (Fig. 9A-B-D). The existence of overconsolidation of the lower units at Pen Hat, of a level of load casts in unit PH 5, and of a younger oriented water escape features in unit PH4-5, confined in space by unit PH6, argue for a series of earthquakes. PH4 yielded an ESR age of $403 \pm 70 \mathrm{ka}$, suggesting the largest liquefaction events are younger, but older than PH7, a MIS 7a tidal complex (Fig. 4). The load cast event (PH5) is thus slightly younger than $403 \pm 70 \mathrm{ka}$.

\section{Kergleuz section}

The Kergleuz section is located at the outlet of the Elorn valley, on an abrasion terrace on the right bank of the Elorn estuary (N 48.393641106375576, W -4.4048690826451775) (Fig. 1b), at an elevation of $30 \mathrm{~m}$ NGF. The Elorn Fault System morphologically controls this part of the valley. Most of the sediments are clays and are preserved in a 12-m-deep, and 150-m-wide incision cut within quartz-rich shale. The fluvial infilling (Fig. 3) mostly consists of Zanclean and early Quaternary deposits (Darboux et al., 2010).

\section{Description}

A complex deformation system is evident from the stratigraphy proposed by Hallégouët (1994). Deformations mostly affect the Piacenzian and Gelasian sands (ESR dating to $2.4 \pm 0.35 \mathrm{Ma}$ ) and terrace gravel that rest on Zanclean clayey infratidal sediments (Darboux et al., 2010). These deformation structures are truncated by the periglacial slope deposits resting of the lower unit of the Middle Terrace group (unit Fxa of the french geological map; Darboux et al., 2010), deformed like the Gelasian unit in the western wall of the Kergleuz section (Fig.10). Clay layers are folded mostly synclinally, before being truncated by the $30 \mathrm{~m}$ a.s.l thin alluvial terrace Fxa. Fold limbs are limited by upward vertically injected sand masses, and by 3 to 4 vertical large mud escapes of about 5 $\mathrm{m}$ wide (in yellow on Fig. 10B). These sand-escape diapirs are similar in shape and size to those of the clayish structure A at Trez Rouz. Shortening structures, dehydration fissures, and clay layer brecciation, provide evidence for liquefaction and possible load casts (Fig. 10). The periglacial head cover is not deformed. Frost wedges are often superimposed on diapirs. The basal Zanclean tidal clays are only subject to wavy deformation. Frost wedges (Fig. 10B), probably sand wedges, postdate most of the deformations.

\section{Interpretation}

The setting up of the Fxa Terrace basal surface likely occurred in the late Miocene (western and northern France; Van Vliet-Lanoë et al., 2002), during the opening of the Bay of Brest. The age of this terrace is not accurately known, but could be considered to be $\sim 400$ ka by comparison with similar ESR dated Fxa deposits in northern and north-western France (Bahain et al., 2007; Cordier et al., 2006; Voinchet et al., 2010) (Fig. 4). The first major development of frost wedges in Brittany occurred in MIS 8 (280-240 ka; Pénestin section, Van Vliet-Lanoë et al., 1997; Van Vliet-Lanoë et al., 2009). The upper boundary of the Fxa terrace unit is deformed, its deformation might have occurred around the same time (same event?) as in Trez Rouz and Pen Hat (Fig. 3). 


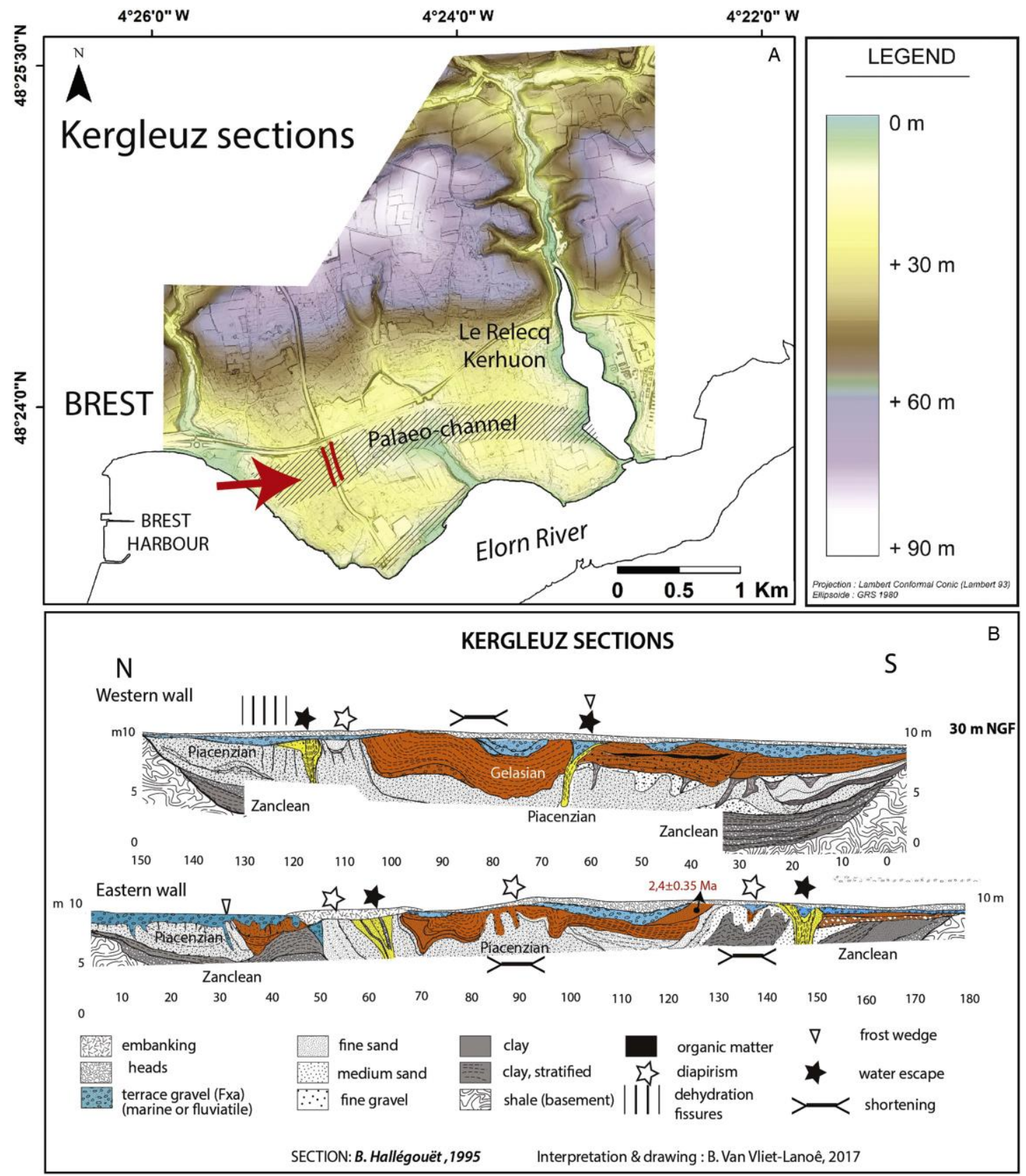

Figure 10. Deformation at Kergleuz during the 1995 excavation of the highway across a paleochannel. (A) Location of the section on a digital elevation model: sections in red. (B) Sections. In yellow: main water-escape features. Blue: ca. $430 \mathrm{ka}$ Fxa gravel terrace. Orange:Gelasian ( 2.4 Ma). Please note the different vertical and horizontal scales.

The Gurp section (Gironde estuary, N. 45.434478706670085, W -1.1530494689941406)

\section{Background.}

Observations performed on this site (Fig. 1A and 5) occur in the vicinity ( $<30 \mathrm{~km})$ of the SASZ, in the entrance to the Gironde estuary (Mazabraud et al., 2005; Mazabraud et al., 2013) (Fig. 2). Present-day seismicity in this zone is significant, with historical earthquakes up to $\mathrm{M}_{\mathrm{w}} 6$ (SiHex, Cara et al. 2005, Manchuel et al., 2017). The stratigraphy of the section was described by Tastet (1999), which describes several units of clay, sands, and peats. The stratigraphic position of the Gurp clay topped with peat (called "lignite") (Fig. 4) was attributed to the 
ends of MIS 11 or MIS 9 (Diot, 1999; O'Brien and Jones, 2003). Recently, Sitzia et al. (2015), using ESR methods, dated the Amelie Sands located above the peat to $217 \pm 31$ and $222 \pm 31$ ka (Fig. 3), who correlated this unit to MIS 8 (243-280 ka).

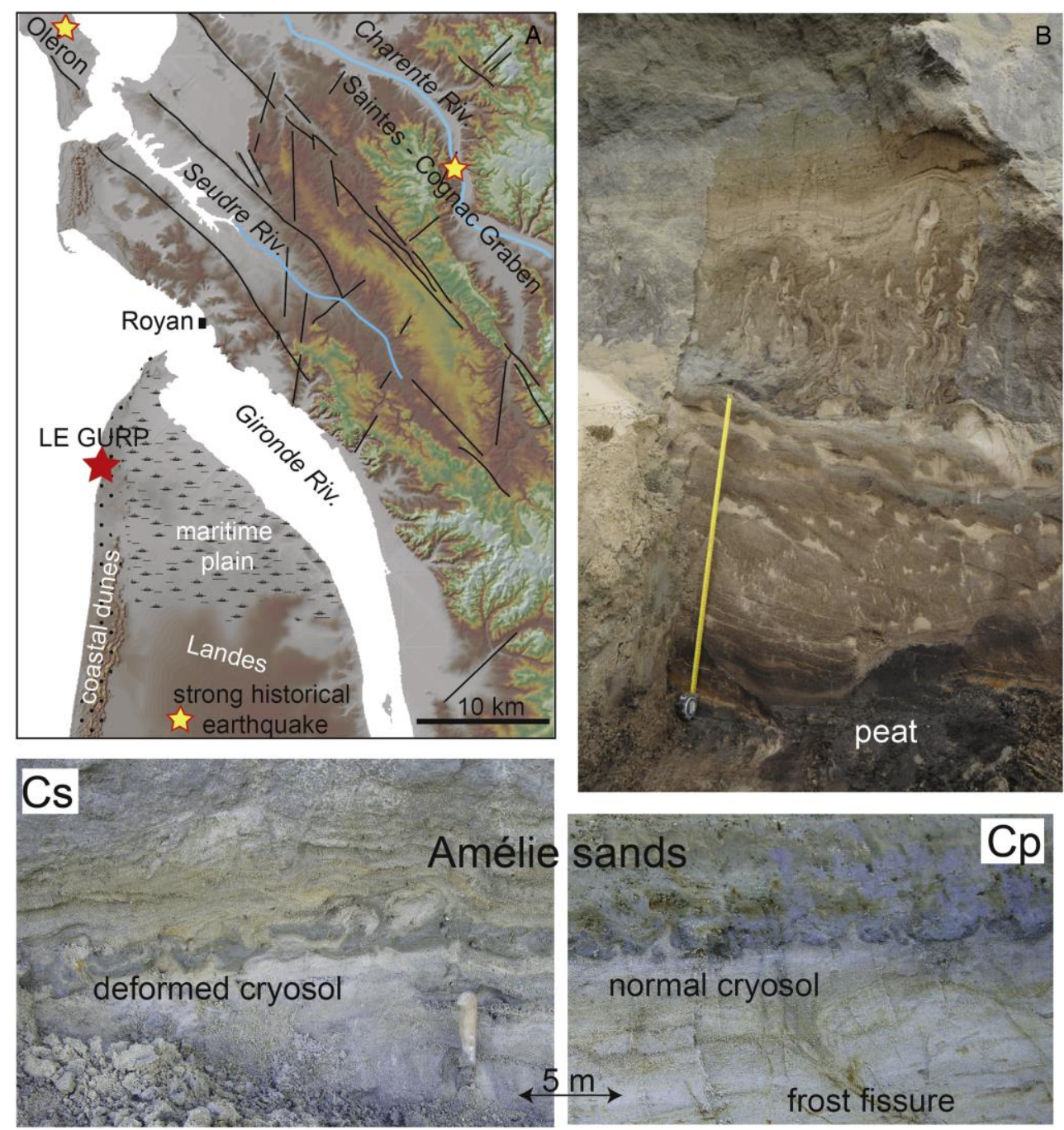

Figure 11. (color online) Le Gurp study site. (A) Regional digital elevation model. (B) Coseismic involutions above the Le Gurp peat (courtesy J.L. Schneider). (Cp) Small, periglacial ground pattern in the Amélie Sands. (Cs) The same unit deformed by liquefaction.

\section{Description}

The Holstenian (MIS 9) littoral deposits are mechanically deformed by successive events of load casts. Here, deformations in the clay ( $2 \mathrm{~m}$ thick) show sliding planes stained with iron hydroxides and load casts, associated with upward clay injection into the peat, leading to macroscopic circular patterns called pseudo-pingo features (Dubreuilh, 1976; Dubreuilh and Marionnaud, 1973). These features are affected by a retraction fissure set and brecciation, which suggests a post-deformational dehydration. Beneath the peat, the lower part of the Amélie sands display ground patterned by small cryogenic features, disturbed by clustered liquefaction features (Fig. 11) comparable to load casts in seismic settings (Van Vliet-Lanoë et al, 2005).

\section{Interpretation}

The ages of the Gurp unit should be similar to that of the Trez-Rouz site with stacked and deformed coastal interglacial deposits close to today's sea level, although deformations are commonly attributed to periglacial 
features (Tastet, 1999; Sitzia et al. 2015; Andrieux et al., 2017). Despite the interpretations of Sitzia et al. (2015) that correlated the Amélie sands with MIS8, we chose to use the stratigraphic position provided by the ESR dating ( $217 \pm 31$ and $222 \pm 31 \mathrm{ka})$ consistent with the MIS7. The estuarine sand, beneath the Amélie sands, separated by a major discontinuity with a paleosol, and above the MIS 11 peat, was correlated with MIS 9 . According to our observations, the Gurp section shows at least two main events: 1) at the end of MIS 11, after the peat formation and before the estuarine sands deposition; and 2) at the end of MIS 9, older than the Amelie sands but younger than the estuarine sands, late MIS 7 based ESR dating. The lower part of the Amelie sands also shows evidence of smaller and younger events during the middle MIS 7.

\section{DISCUSSION}

\section{Arguments for seismically-induced deformations}

Before this study, deformation structures at Trez Rouz, Pen Hat, and Kergleuz were considered to be a result of periglacial processes (Hallegouët, 1989; Mellou, 1968; Morzadec-Kerfourn, 1974), despite the lack of syngenetic evidence of segregated ice. However, the numerous features shown allow us to argue that deformations took place during or just after interglacial stages (MIS 11 and 9, Fig. 4). With this timing, the deformations should have been produced by other processes, seismic events being the most probable (see Table $1)$.

Neither fault reactivation nor diagnostic evidence of frost mounds has been found at Trez Rouz or Kergleuz despite evidence of late permafrost during MIS $8 \mathrm{a}$ and 2. The only periglacial features present are scarce frost fissures, ploughing block involutions, clast or cobble frost jacking, and bending of features by frost creep.

Most of the younger deformed units highlighted in this study indicate that they formed at a sea level close to the present day, thus in temperate to boreal conditions (MIS 11 and MIS 9a deposits, Fig. 4). Indeed, the MIS 9e, MIS 11a, and MIS 13a highstands have regionally reached +20 to $+30 \mathrm{~m}$ (corresponding to the Middle Terrace Fx in estuaries), while the MIS 9a and MIS 5e are closer to today's sea level along the coast of Western Europe (Van Vliet-Lanoë et al., 2000). The age of the youngest units affected, deduced by ESR dating and the stratigraphic puts them at MIS 11,9a/8c. Stratigraphic evidence suggests that palaeo-earthquakes occurred during the onset of a cooling period with a limited glacio-eustatic regression (Fig. 4). This scenario postulates that the sea-level dropped only by 10 to $20 \mathrm{~m}$ below it interglacial maximum of +20 and $-30 \mathrm{~m}$ during MIS 11a and 9a, respectively for most of the events considered in our study. At Trez Rouz, a sea level close to today's is likely for the youngest seismic event is supported by the occurrence of jarosite along structure A. This implies the likelihood of a persisting brackish water prism persisting at these sites when the deformation occurred.

Furthermore, deformations observed at Trez Rouz above the thickest body of saprolite $(25 \mathrm{~m})$ needed large water storage at depth to have occurred (Figs. 3 and 4). Deformations are probably enhanced by recurrent liquefaction and a down slope mass movement, occurring when the water table was high. This situation occurs rarely during glacial stages. Deformations affecting the thickest alluvial layer $(15 \mathrm{~m})$ in the Kergleuz incision also suggest a high elevation of the water table. Erosional features visible at Trez Rouz, Pen Hat, and Kergleuz indicate overconsolidation processes and superficial fissuring of the deformed zones. Large water escapes structures also exist at Kergleuz (Fig. 11), but their age is hard to determine more accurately than Lower or Middle Quaternary. The occurrence of subsurface overconsolidation of the saprolite or in the clayey units in the three sites, as well as intraclast formation (Kergleuz) or brecciation, or mud injection or water escape, suggests a rapid liquefaction and deformation in agreement with an assumption involving earthquakes (Van Vliet-Lanoë et al., 2009). The development of large deformations and shortening with injections may be related to a slower motion of the affected units over at least several days after the seismic initiation since it progressively affects the base of the overlying units.

\section{Co-seismic liquefaction and sediment deformation by clay diapirism}

Detailed observations made on the three studied sites allow us to determine the likely mechanisms of deformation. Similar superficial liquefaction features associated with clay diapirism were already attributed to 
Middle Quaternary seismic activity south of the study zone in the Vilaine Estuary (Fig. 2; Van Vliet-Lanoë et al., 2009).

Liquefaction susceptibility reflects the relative resistance of soils (sandy or silty) to loss of fabric and strength when subjected to ground shaking. As water is a non-compressible fluid, the alternating squeezing and suction produced by vibrations from the local water table in the faulted palaeozoic basement induces an excess of pore water pressure, exceeding the liquid limit (Woith et al., 2003). Oversaturation is reached by fabric destruction (unconsolidated sand or porous saprolite) and/or by co-seismic water pumping (Sibson, 1994, Muir-Wood and King, 1993) leads to loss of soil strength and liquefaction, or even fluidization (Sibson, 1994; Montgomery and Manga, 2003; Derakhshandi et al., 2007). With fluidization and a very low dynamical viscosity, buoyancy forces and hydraulic fracturing develop in the confining layer, with differential loading (Bolton and Maltman, 1998). During the hydrofracturing process, an inner hydraulic pressure gradient was probably involved in tension gashes opening and forming "clastic" dykes in peat (Sibson, 1994; Levi et al., 2006). These processes also allowed: 1) an incipient swell or doming that stretched the overburden cover (Powley, 1999): 2) mud injected close to its apex within the confining layer: and 3) an upward stretching and thinning of the flanking units (Figs. 5, 7A) (Van Vliet-Lanoë et al., 2009). Youd et al. (2004) showed that ground oscillations during an earthquake led to a continual rise of pore water pressure after ground-shaking ceases, triggering the prolonged post-shock deformation. When the hydraulic pressure is lowered by dewatering, the clay diapirism normally stops, and the processes of consolidation begin, followed by a later collapse (Powley, 1999). Co-seismic pumping also leads to overconsolidation of sediments at depth by water expulsion to the surface, although the superficial layers are first liquefied and further overconsolidated after desiccation (Youd et al., 2004). This could explain the late retraction fissures that formed by desiccation in the zones suspected to have been liquefied, especially at the Trez Rouz and Kergleuz sites.

Co-seismic liquefaction is commonly studied in sands (e.g., Obermeier et al., 1993). Since kaolinite-rich saprolites behave as quick clays along shore cliffs exposed to the swash impact of waves, it is better to use the term clay diapirism instead of shale diapirism in our study. This mechanism, already well observed at Pénestin (Van Vliet-Lanoë et al., 2009), and could explain most of the mesoscopic deformation structures observed in saprolites at the Kergleuz and Trez Rouz sites> Which includes the extension in sands (unit TRZ 5) and retraction fissures developed by dewatering and desiccation in the injected saprolite or liquefied sediments. The collapse of the interstitial porosity by vibration also explains why any remobilization by a latter event is almost impossible in sands and in saprolites. The mechanisms are not fundamentally different in both materials. Furthermore, clay diapirism also explains shortening fabric in partly consolidated material in the same places.

The stretching by solifluction and/or thinning of the overburden alluvial body, upslope at Trez Rouz, limited the confining pressure for the injection in structure A. Moreover, post-diapirism consolidation could have prevented a renewed liquefaction in the same location. This is also true for structures B to C, leading to the transfer of the liquefaction zone to the northern part of the graben (structure A). The confining of the saprolite under the accumulation of TRZ 9 slope deposits at the northern edge of the graben, and the absence of pre-existing overconsolidation, facilitate the upward migration of the saprolite in structure A (Fig. 7 phase IV).

\section{Impact of altered Variscan structures on the deformation initiation}

The main deformation process highlighted at Trez Rouz, Kergleuz, and Pénestin (Van Vliet-Lanoë et al., 2009) is a small-scale clay diapirism, initially triggered by co-seismic water pressure. Further loading and lateral spreading on an already deformed and deeply-weathered shale bedrock allowed the clay diapirism to develop. The initial bulge shape, induced by liquefaction, is modified by lateral or oblique upward migration of fluidized clays and may generate a network of clay dykes or sand pipes, as happened at Pen Hat. In classical clay diapirism, the diapirs usually develop in the form of ring or conic faults, which enhance the rise of the diapir. Here, and in all other studied sites, the bulge shape is parallel to the water escape from the basement, leading to injection swarms roughly parallel to the basement faults. This localized overpressure source results in tension gash development in the confining stratified alluvial system, accumulated in a trough to the south of structure B 
at Trez Rouz (Fig. 3). The folds and injections are parallel to the main basement structures, but also to the orientation of the pre-existing confined channel sedimentary pattern (TRZ 6b; Fig. 8, phase I). The parallelism between sand fissures and channels is similar to the sand dikes along the Mississippi river caused by the New Madrid 1811 and 1812 earthquake (Obermeier, 1996). The absence of surface fault rupture and the sub-parallel characteristic of the injections related to the basement faults result from a mechanism of water injection from basement faults into the capping saprolite (Fig. 3A). Mechanically, the water-table level must not be deeper than $5 \mathrm{~m}$ from ground level to create these structures (Olson et al., 2005).

Clay diapirism is rather common in Europe, for instance, in the Oligocene Bovey-Tracey basin located in Devon in the UK along the Sticklepath Fault (STK; Fig. 2, Van Vliet-et al., 2009), and in the lignite grabens in Germany and Poland (Eissmann 1987). Site effects (Semblat et al., 2005) on unconsolidated sedimentary bodies certainly amplified the liklihood of diapirism in all the studied sites near Variscan structures. The minimal thickness of saprolite needed to cause diapirism is about $10 \mathrm{~m}$, as evident at Pénestin and Kergleuz.

\section{Seismo-tectonic significance}

Currently, accommodation of the regional plate deformation is recorded, along plate shearing zones (mostly Variscan shearing zones, Mazabraud et al., 2013) based on the focal depth for most of the studied events. The present-day stress field is NW-SE with a clear strike-slip signature and a slight W-E transtensive component in Brittany (Olaiz et al., 2009). Seismic analysis produced after the Lorient/Hennebont earthquake in $2002\left(\mathrm{M}_{\mathrm{w}} 4.3\right.$ or Lg 5.4 magnitude scales) along the SASZ, indicates a main $170^{\circ}$ trending regional stress field (Perrot et al., 2005). No fault displacement affecting the surface has been detected from this event or during the historical period. Generally, the regional seismicity is rather low. No mud volcanoes has ever been observed on the Holocene mudflats of the Bay of Brest after the recent earthquakes (e.g., 11/10/13, 11/12/13, 30/10/15, 8/12/16, 11/12/16, 24/01/18: MI 3.4 to 3.9, instrumental magnitude according to CEA network) or after the recent, major Hennebont (2002; $\mathrm{M}_{\mathrm{w}}$ 4.3) and Quimper (1959; $\mathrm{M}_{\mathrm{w}}$ 5.4) earthquakes. Nevertheless, Holocene submarine slumps in estuarial clays are present at the entrance of the Elorn Estuary (Grégoire et al., 2017, Fig. 1B: S). Clay diapirism associated with liquefaction has only been observed in middle Pleistocene deposits in this region. This process needs specific conditions that do not currently occur in Brittany and surrounding areas, despite the fact that environmental conditions look similar between the middle Pleistocene and today, notably from a sedimentary and sea level points of view (relative sea level close to the 0 NGF ; see section 5.1). Therefore, as for middle Pleistocene peat deposits, Holocene mudflats in the Bay of Brest could easily be marked by mud ejection above basement faults in case of a major earthquake.

The only major regional faults able to generate strong earthquakes are the Elorn and the Kerforne fault systems, and the South Amorican Shear Zone (SASZ) (Figs. 1 and 2). The major one system, the SASZ is the farthest away, $>25 \mathrm{~km}$, from our studied sites, while the other faults exist at depth beneath our studied sites (Fig. 1). To estimate the range of magnitudes possible to explain the palaeo-earthquakes, we considered regional magnitude-bound relations adapted from stable continental regions, based on relationships between earthquake magnitude and the most distal occurrences of level-ground liquefaction from the earthquake source (Obermeier et al., 1993; Olson et al., 2005), since no magnitude-bound relationships are available for Brittany. Based on the minimum distance between the studied sites and the SASZ $(25-40 \mathrm{~km})$, a minimum $\mathrm{M}_{\mathrm{s}}$ of 6.4 to 6.9 is required to produce liquefaction at the studied sites $\left(\mathrm{M}_{\mathrm{s}}\right.$ values are similar to $\mathrm{M}_{\mathrm{w}}$ when they are greater than 5.5; Lolli et al., 2014). For the other two faults, located closer, a $M_{s}$ of 5.5 is enough. If we consider that a saprolite has a high liquefaction susceptibility, due to its fragile porous fabric, the required minimum $\mathrm{M}_{\mathrm{s}}$ for an earthquake along the SASZ can be reduced to an $\mathrm{M}_{\mathrm{s}}$ of 6 to 6.4 and reduced to $\mathrm{M}_{\mathrm{s}} 5$ for the closest faults (Kerforne and Elorn faults).

Moreover, because earthquakes occurring during periods of relatively high sea levels and consequently high water tables, with site amplification the magnitude need not be so high for significant deformatoon. Indeed, the discharge created by a lowering sea level could open the fissures, promoting deeper water infiltration, reducing the friction and thus limiting the accumulation of strain, especially on shale or clay. Fluid pressure would 
propagate as slow stress waves along fissure paths and could enhance the effects of earthquakes (Mulargia and Bizzarri, 2014, Segall and Rice, 1995; Sibson 1994).

\section{Geodynamic significance}

Any Mw 5 earthquake along the Kerforne and Elorn Faults, or Mw 6 earthquake along the SASZ, is documented by historical and instrumental seismicity, but the possibility that such events occurred during the Quaternary cannot be excluded. Indeed, according to the length-magnitude scaling relationship (Wells and Coppersmith, 1994), the 40-km-long Elorn and Kerforne faults and the 100-km-long segments of the SASZ possibly could generate earthquakes of a maximum magnitude $\sim 6.8$ and $\sim 7.4$, respectively. Recently, Calais et al. (2016) suggested that large earthquakes in intraplate contexts such as in Brittany do not obey the seismic recurrence cycle, such as those located at the frontiers of plates. Moreover, the authors suggest that large earthquakes in stable continental regions are better explained by transient perturbations of local stress on fault strength that release elastic energy from a prestressed lithosphere.

From the stratigraphic analysis and the available dating, at least two periods of clusters of earthquakes are evident in western France: (1) at the onset of MIS 10, $380 \mathrm{ka}$, and (2) at the onset of MIS8, 280-265 ka (Fig. 3 ). No older or younger important deformations is evident, except some younger events in the Aquitaine during the Younger Dryas stade (Schneider et al., 2012). The second period (280-265 ka) is frequently associated with other potential paleoseismic events in western Europe. It could be the case for major falling down of the Sangatte paleocliff, the Cagny Epinette living-floor faulting in the Somme valley, and recurrent load casts in saprolite in central Brittany (Fig. 2; Van Vliet-Lanoë et al., 2002). Nevertheless, some deformations such as reverse faulting affecting the $160 \mathrm{ka}$ loesses of Sangatte are now interpreted as thermokarstic features (Van Vliet-Lanoë et al., 2017). Sediment records in our study zone are incomplete because of lack of exposures (McCalpin, 1996; Caputo, 2005; Beck, 2009), so other earthquakes may have been missed. We highlight many discontinuities in the records, even when overconsolidation normally limits the erosion efficiency (see Fig. 3). Dating and paleoclimate records clearly indicate that the seismic events occurred during the onset of MIS 10 and 8 , so we postulate that these two periods of seismic events could be triggered by of the rapid growth of major ice sheets (particularly MIS 10; Van Vliet-Lanoë et al., 1997, 2002). We did not highlight any paleoseismic events at the onset of the glaciations that are more recent than MIS 8 in western France. The Gurp section, located closer to the Alpine sutures, is still active.

However, the ice caps of the less extensive subsequent glaciations (MIS 6, 4, 2) could be too small and too far away from the study zone to produce a forebulge that adequately deforms the Armorican massif lithosphere and adequately increases the stress loading. Also, some cryogenic consolidation of the saprolite (permafrost) and old tidal muds during the cold Saalian I (MIS 8; 280-240 ka) could prevent new liquefaction during the onset of more recent glaciations. Glacio-isostatic stress perturbation is not the only factor that could trigger a major earthquake in Brittany. Internal Earth dynamics such as, for example, changes in pressure driven flow within the asthenosphere or slab sinking could also bring answers to the origin of these middle Pleistocene intraplate seismic events.

Indeed, these paleoearthquakes could have been induced by the African-Eurasian plate convergence, and, more precisely, a brief acceleration of plate motion during the investigated period is possible (Iaffaldano and Bunge, 2015). This convergence is also postulated as the origin of other paleoseismic events during the same period, occurring to the south of the studied zone, closer to the plate boundary. For instance, on the northern foot slope of the Pyrenean mountains, superficial ruptures have been evidenced, deforming the upper terrace of the Adour River at Meilhan dated to $<500 \mathrm{ka}$ (Fig. 2; Carbon et al., 1995). Moreover, to the south of the Western Alps, coseismic ruptures dated to between 100 and $300 \mathrm{ka}$ occurred along the Trévaresse Fault (Fig. 2; Aix-en-Provence: Chardon et al.,2005). Additionally, orbital forcing enhanced by solar activity and affecting Earth's rotation velocity could be envisaged as another source of lithospheric loading favoring seismic periods (Bendick and Bilham, 2017). This forcing also influences the climate and dynamic processes in the liquid metallic core of Earth controlling the magnetic field (Hide and Dickey, 1991; Worm, 1997; Encrenaz et al., 2003; Laut, 2003). Perturbations in the deepest part of Earth could also affect the stress field near the surface by possibly accelerating mantle convection and plume activity in the asthenosphere (Larson and Olson, 1991; 
Worm, 1997). Curiously, the highlighted seismic periods occurred during the onset of glaciations and at the same time as two magnetic low (geomagnetic low dipole) periods at 380 and 280 ka (Worm, 1997; Ménabréaz et al., 2014)

\section{CONCLUSION}

The combined examination of dating, geomorphology, sedimentological, and palaeoecological data from sites with Quaternary deformations in Western Brittany allow for an analysis of the conditions that drive palaeoseismicity in an intraplate region of Europe. From a mechanical point of view, clay diapirism development and liquefaction in regions with limited tectonic activity is linked to the occurrence of an unconsolidated sedimentary or saprolitic clay unit, with the presence of a rather shallow water table and a confining surface layer. The triggering seismicity is not necessarily important (not much higher than present-day) and is probably associated with site effects. From a geodynamical point of view, two periods of co-seismic events are evident: during early MIS $10(\sim 380 \mathrm{ka})$, and early MIS 8 ( 280-265 ka). They may be associated with the dynamics of Africa-Eurasia's plate convergence, in part accommodated in the far field by reactivation of major shear zones (Fig. 2). Still open to discussion is the possible glacio-isostatic impact on the stress field during the onset and decay of ice sheets together with their forebulge dynamics and to the influences of orbital forcing on lithospheric loading.

\section{Acknowledgements}

This research did not receive any specific grant from funding agencies in the public, commercial, or not-for-profit sectors. We first thank the "Reserve Naturelle Régionale de Crozon" in Brittany to have allowed the complementary sampling for new IRSL dating at Pen Hat. We thank especially Jamie Shulmeister and Roy Van Arsdale for their constructive recommendations to improve our paper as well in scientific clearness as in language. We thank also an anonymous French reviewer for his judicious comments on the French seismic activity.

\section{References}

Andreieff, P., Bouysse, P., Horn, R., Monciardini, C., 1972.Contribution à l'étude géologiques des approches de la Manche.Mémoires du Bureau de recherches géologiques et minières 79,31-48.

Andrieu-Ponel, V., Demory, F., Perrin, M., Cihat Alcicek, M.,Lebatard, A.-E., Nomade, S., Djamali, M., Rochette, P., Helvac1, C., 2016. The long climatic sequence of Acigol Lake, NW Turkey: first chronological and palynological results. 25eme Réunion des sciences de la Terre, Caen, France.

Anell, I., Thybo, H., Artemieva, I.M., 2009. Cenozoic uplift and subsidence in the North Atlantic region: geological evidence revisited. Tectonophysics 474, 78-105.

Arroucau, P., 2006. Sismicité du Massif armoricain: relocalisation et interprétation tectonique. PhD dissertation, Earth Sciences, University of Nantes, Nantes, France.

Bahain, J.J., Falguères, C., Laurent, M., Voinchet, P., Dolo, J.M., Antoine, P., Tuffreau, A., 2007. ESR chronology of the Somme River Terrace system and first human settlements in Northern France. Quaternary Geochronology 2, 356-362.

Ballèvre, M., Bosse, V., Ducassou, C., Pitra, P., 2009. Palaeozoic history of the Armorican Massif: models for the tectonic evolution of the suture zones. Comptes Rendus Geoscience 341, 174-201.

Beck, C., 2009. Late Quaternary lacustrine paleo-seismic archives in north-western Alps: examples of earthquake-origin assessment of sedimentary disturbances. Earth-Science Reviews 96, 327-344.

Bendick, R., Bilham, R., 2017. Do weak global stresses synchronize earthquakes? Geophysical Research Letters $44,8320-8327$.

Bergerat, F., 1987. Stress fields in the European platform at the time of Africa-Eurasia collision. Tectonics 6, 99-132.

Bessin, P., Guillocheau, F., Robin, C., Schroëtter, J.-M., Bauer, H., 2015. The Armorican Massif (western France): a two times exhumed relief shaped by planation surfaces in response to Iberia-

Eurasia relative movements. Geomorphology 233, 75-91.

Bolton, A., Maltman, A., 1998. Fluid-flow pathways in actively deforming sediments: the role of pore fluid 
pressure and volume change. Marine and Petroleum Geology 15, 281-297.

Bonnet, S., Guillocheau, F., Brun, J.-P., Van Den Driessche, J., 2000. Large-scale relief development related to Quaternary tectonic uplift of a Proterozoic-Paleozoic basement: the Armorican Massif, NW France. Journal of Geophysical Research 105, 19273-19288.

Cagnard, 2008. Carte géologique harmonisée du département du Finistère. BRGM/RP-56273-FR, BRGM ed., $435 \mathrm{pp}$.

Calais, E., Camelbeeck, T., Stein, S., Liu, M., Craig, T.J., 2016. A new paradigm for large earthquakes in stable continental plate interiors. Geophysical Research Letters 43, 10621-10637.

Caputo, R., 2005. Ground effects of large morphogenic earthquakes. Journal of Geodynamics 40, 113-118.

Cara, M., Cansi, Y., Schlupp, A., Arroucau, P., Béthoux, N., Beucler, E., Bruno, S., et al., 2015. SI-Hex: a new catalogue of instrumental seismicity for metropolitan France. Bulletin de la Société Géolologique de France 186, 3-19.

Carbon, D., Combes, P., Cushing, M., Granier, T., Grellet, B., 1995. Rupture de surface post-Pléistocène moyen dans le Bassin Middle Pleistocene seismically induced clay diapirism in an intraplate zone, western Brittany, France 21 https://www.cambridge.org/core/terms. aquitain. Comptes Rendus de l'Academie des Sciences, Serie Iia 320, 311-317.

Chardon, D., Hermite, D., Ngyen, F., Bellier, O., 2005. First paleoseismological constraints on the strongest earthquake in France (Provence) in the twentieth century. Geology 33, 904-911.

Chauris, L., Plusquellec, Y., Hallegouët, B., Darboux, J.-R., Melou, M., Chauvel, J.-J., Le Corre, C., Babin, C., Morzadec, P., Thonon, P., 1980. Notice de la carte géologique 1/50 000, feuille Brest (274). Bureau de recherches géologiques et minières, Orléans, France.

Cordier, S., Harmand, D., Frechen, M., Beiner, M., 2006. Fluvial system response to Middle and Upper Pleistocene climate change in the Meurthe and Moselle valleys (Eastern Paris Basin and

Rhenish Massif). Quaternary Science Reviews 25, 1460-1474.

Darboux, J.R., Marcoux, E., Hallégouët, B., Lebret, P., Thomas, E.,Margerel, J.-P., Blanchet, S., Carn, A., 2010. Notice explicative, Carte géol. France (1/50 000), feuille Landerneau (239). Bureau de recherches géologiques et minières, Orléans, France.

Derakhshandi, M., Rathje, E.E., Hazirbaba, E.E., Mirhosseini, S.M.,2007. The effect of plastic fines on the pore pressure generation characteristics of saturated sands. Soil Dynamics and Earthquake Engineering 28, 376-386.

Diot, M.F., 1999. Le Pléistocène de la façade atlantique du Nord- Médoc (France): synthèse sur la palynologie des «Argiles du Gurp» s.l. et comparaison avec les données de l'Aquitaine. Quaternaire 10, 213-225.

Dubreuilh, J., 1976. Contribution à l'étude sédimentologique du système fluviatile Dordogne-Garonne dans la région bordelaise. Les ressources en matériaux alluvionnaires du département de la Gironde. $\mathrm{PhD}$ dissertation, Université de Bordeaux, Bordeaux,France.

Dubreuilh, J., Marionnaud, J.M., 1973. Notice explicative, carte géologique de la France (1/50000), feuille St-Vivien de Médoc - Soulac-sur-Mer (730). Bureau de recherches géologiques et minières, Orléans, France.

Eissmann, L., 1987. Lagerungsstörungen im Lockergebirge: Endogene und exogene Tektonik im Lockergebirge des nördlichen Mitteleuropas. Geophysik und Geologie 3, 7-78.

Encrenaz, T., Bibring, J.-P., Blanc, M., 2003. The Solar System. Springer, Berlin.

Field, M.H., Velichkevich, F.Y., Andrieu-Ponel, V., Woltz, P., 2000. Significance of two new Pleistocene plant records from western Europe. Quaternary Research 54, 253-263.

Gély, J.P., Sztràkos, K., 2000. L'évolution paléogéographique et géodynamique du Bassin aquitain au Paléogène: enregistrement et datation de la tectonique pyrénéenne. Géologie de la France 2, 31-57.

Giardini, D., Woessner, J., Danciu, L., Cotton, F., Crowley, H., Grünthal, G., Pinho, R., et al., 2013. Seismic Hazard Harmonization in Europe (SHARE): Online Data Resource (accessed). http://dx.doi.org/10.12686/SED-00000001-SHARE. Last accessed May 2017.

Golke, M., Coblentz, D., 1996. Origin of the European regional stress field. Tectonophysics 266, 11-24.

Grégoire, G., Le Roy, P., Ehrhold, A., Jouet, G., Garlan, T., 2017. Control factors of Holocene sedimentary infilling in a semi-closed tidal estuarine-like system: the Bay of Brest (France). Marine Geology 385, $84-100$.

Hallégouët, B., 1989. La presqu'île de Crozon: évolution géomorphologique. Historien- Géographe 318, 141148.

Hallégouët, B., 1994. Formation de la rade de Brest. In: Corlaix, J.-P. (Ed.), Atlas permanent de la mer et du littoral. Editmar No. 1. CNRS, Nantes, France, pp. 22.

Hallégouët, B., Ollivier-Pierre, M.F., Esteoule-Choux, J., 1976. Découverte d'un dépôt oligocène inférieur dans la haute vallée de l'Aber Ildut, au nord-ouest de Brest (Finistère). Comptes Rendus de l'Academie des 
Sciences 283D, 1711-1714.

Haugmard, M., 2017. Détermination non-linéaire des paramètres hypocentraux et structuraux: application à la sismicité intracontinentale du Massif armoricain. PhD dissertation, Earth Sciences, University of Nantes, Nantes, France.

Hide, R., Dickey, J.O., 1991. Earth's variable rotation. Science 253,629-637.

Iaffaldano, G., Bunge, H.-P., 2015. Rapid plate motion variations through geological time: observations serving geodynamic interpretation. Annual Review of Earth and Planetary Sciences 43, 571-592.

Irfan, T.Y., 1996. Mineralogy, fabric properties and classification of weathered granites in Hong Kong. Quarterly Journal of Engineering Geology 29, 5-36.

Ito, K., Tamura, T., Tsukamoto, S., 2017. Post-IR IRSL dating of K-feldspar from last interglacial marine terrace deposits on the Kamikita coastal plain, northeastern Japan. Geochronometria 44,352-365.

Koutsodendris, A., Müller, U.C., Pross, J., Brauer, A., Kotthoff, U., Lotter, A.F., 2010. Vegetation dynamics and climate variabilityduring the Holsteinian interglacial based on a pollen record from Dethlingen (northern Germany). Quaternary Science Reviews 29, 3298-3307.

Lambeck, K., Johnston, P., 2000. Reply to comment by W. Fjeldskaar 'What about asthenosphere viscosity? Sea-level change, glacial rebound and mantle viscosity for northern Europe. Geophysical Journal International 142, 279-281.

Landgraf, A., Kuebler, S., Hintersberger, E., Stein, S. (Eds.), 2016.Seismicity, Fault Rupture and Earthquake Hazards in Slowly Deforming Regions. Special Publication, No. 432. Geological Society, London.

Larson, R.L., Olson, P., 1991. Mantle plumes control magnetic reversal frequency. Earth and Planetary Science Letters 107, 437-447.

Laut, P., 2003. Solar activity and terrestrial climate: an analysis of some purported correlations. Journal of Atmospheric and Solar-Terrestrial Physics 65, 801-812.

Le Gall, B., Authemayou, C., Ehrhold, A., Paquette, J.-L., Bussien, D., Chazot, G., Aouizerat, A., Pastol, Y., 2014. LiDAR offshore structural mapping and $\mathrm{U} / \mathrm{Pb}$ zircon/monazite dating of Variscan strain in the Leon metamorphic domain, NW Brittany. Tectonophysics 630, 236-250.

Le Roy, P., Gracia-Garay, C., Guennoc, P., Bourillet, J.-F., Reynaud, J.-Y., Thinon, I., Kervevan, P., Paquet, F., Menier, D., Bulois, C., 2011. Cenozoic tectonics of the Western Approaches Channel basins and its control of local drainage systems. Bulletin de la Société Géologique de France 182, 451-463.

Levi, T., Weinberger, R., Aïa, T., Eyal, Y., Marco, S., 2006. Earthquake-induced clastic dikes detected by anisotropy of magnetic susceptibility. Geology 34, 69-72.

Lolli, B., Gasperini, P., Vannucci, G., 2014. Empirical conversion between teleseismic magnitudes (mb and Ms) and moment magnitude (Mw) at the Global, Euro-Mediterranean and Italian scale. Geophysical Journal International 199, 805-828.

Manchuel, K., Traversa, P., Baumont, D., Cara, M., Nayman, E., Durouchoux, C., 2018. The French seismic CATalogue (FCAT-17). Bulletin of Earthquake Engineering 16, 2227-2251.

Mansy, J.L., Manby, G.M., Averbuch, O., Everaerts, M., Bergerat, F., van Vliet-Lanoë, B., Lamarche, J., 2003. Role of basement reactivation in the formation and inversion of the Weald-Boulonnais basin. Tectonophysics 373, 161-179.

Marotta, A.M., Mitrovica, J.X., Sabadini, R., Milne, G., 2004. Combined effects of tectonics and glacial isostatic adjustment on intraplate deformation in central and northern Europe: applications to geodetic baseline analyses. Journal of Geophysical Research 109, B01413.

Mazabraud, Y., Bethoux, N., Delouis, B., 2013. Is earthquake activity along the French Atlantic margin favoured by local rheological contrasts? Comptes Rendus Geoscience 345, 373-382.

Mazabraud, Y., Béthoux, N., Guilbert, J., Bellier, O., 2005. Short scale stress determination in central and western France, an intraplate slow deforming region. Geophysical Journal International 160, 161-178.

McCalpin, J.P. (Ed.), 1996. Paleoseismology. Academic Press, San Diego, CA. Melou, M., 1968. Contribution à l'étude sédimentologique du Quaternaire Sud-Finistérien. L'anse de Trez Rouz et la ria de l'Odet. $\mathrm{PhD}$ dissertation, Université de Paris, centre d'Orsay, Paris.

Ménabréaz, L., Thouveny, N., Bourlès, D.L., Vidal, L., 2014. The geomagnetic dipole moment variation between 250 and $800 \mathrm{ka} \mathrm{BP}$ reconstructed from the authigenic 10Be/9Be signature in West Equatorial Pacific sediments. Earth and Planetary Science Letters 385, 190-205.

Montgomery, D.R. and Manga, M. 2003. Streamflow and Water Well Responses to Earthquakes. Science 300, 2047-2049.

Morzadec-Kerfourn, M.-T, 1974. Variations de la ligne de rivage armoricaine au Quaternaire. Analyses polliniques de dépôts organiques littoraux. Mémoiresde la Société géologique et minéralogique de. Bretagne, 17. Institut de géologie, Université de Rennes, Rennes, France.

Morzadec-Kerfourn, M.-T., 1999. Littoraux pléistocènes de l'ouest du Massif armoricain: de la rade de Brest à la 
Baie d'Audierne. Quaternaire 10, 171-179.

Muir-Wood, R., King, G.C.P., 1993. Hydrologic signatures of earthquake strain. Journal of Geophysical Research 98, 22035-22068.

Mulargia, F., Bizzarri, A., 2014. Anthropogenic triggering of large earthquakes. Scientific Reports 4, 6100.

Nocquet, J.M., 2012. Present-day kinematics of the Mediterranean: a comprehensive overview of GPS results. Tectonophysics 579, 220-242.

Obermeier, S.F., 1996. Using liquefaction induced features for palaeoseismic analysis. In: McCalpin, J. (Ed.), Paleoseismology. Academic Press, San Diego, CA, pp. 331-396.

Obermeier, S.F., Martin, J.R., Frankel, A.D., Youd, T.L., Munson, P.J., Munson, C.A., Pond, E.C., 1993. Liquefaction Evidence for One or More Strong Holocene Earthquakes in Wabash Valley of Southern Indiana and Illinois, with a Preliminary Estimate of Magnitude. U.S. Geological Survey Professional Paper 1536. U. S. Government Printing Office, Washington, DC.

O'Brien, C.E., Jones, R.L., 2003. Early and Middle Pleistocene vegetation history of the Medoc region, southwest France. Journal of Quaternary Science 18, 557-579.

Olaiz, A.J., Muñoz-Martín, A., De Vicente, G., Vegas, R., Cloetingh, S., 2009. European continuous active tectonic strain- stress map. Tectonophysics 474, 33-40.

Olson, S., Green, R., Obermeier, S.F., 2005. Revised magnitudebound relation for the Wabash Valley seismic zone of the central United States. Seismological Research Letters 76, 756-771.

Perrot, J., Arroucau, P., Guilbert, J., Déverchère, J., Mazabraud, Y., Rolet, J., Mocquet, A., Mousseau, M., Matias, L., 2005. Analysis of the Mw 4.3 Lorient earthquake sequence: a multidisciplinary approach to the geodynamics of the Armorican Massif, westernmost France. Geophysical Journal International 162, 935-950.

Plusquellec, Y., Rolet, J., Darboux, J.-R., Bosold, A., Chantraine, J.,Chauris, L., Chauvel, J.-J., et al., 1999. Notice explicative de lafeuille Châteaulin, 1/50 000. Bureau de recherches géologiques et minières, Orléans, France.

Powley, D.E., 1999. Shale Domes. Search and Discovery Article\#60001. Revised from Amoco Production Company report. http://www.searchanddiscovery.com/documents/Shale/shale.htm.

Railsback, L.B., Gibbard, P.L., Head, M.J., Voarintsoa, N.R.G., Toucanne, S., 2015. An optimized scheme of lettered marine isotope substages for the last 1.0 million years, and theclimatostratigraphic nature of isotope stages and substages.Quaternary Science Reviews 111, 94-106.

Rohling, E.J., Grant, K., Bolshaw, M., Roberts, A.P., Siddall, M.,Hemleben, C., Kucera, M., 2009. Antarctic temperature andglobal sea level closely coupled over the past five glacial cycles.

Nature Geosciences 2, 500-504. Rolet, J., 1997. The concealed basement of Aquitaine. Mémoires de la Société géolologique de France 171, 115-141.

Schneider, J.L., Van Vliet-Lanoë, B., Sitzia, L., 2012. Déformations co-sismiques à Cestas-Pot-aux-Pins et Larrusey. In:Bertran, P., Lenoble, A. (Eds.), Le Quaternaire continental d'Aquitaine: Un point sur les travaux récents. Field Guide. Association Française pour l'Etude du Quaternaire, Talence, France, pp. $140-152$.

Scourse, J.D., Haapaniemi, A.I., Colmenero-Hidalgo, E., 2009.Growth, dynamics and deglaciation of the last British-Irish ice sheet: the deep-sea ice-rafted detritus record. Quaternary Science Reviews 28, 30663084.

Segall, P., Rice, J.R., 1995. Dilatancy, compaction, and slip instability of a fluid-infiltrated fault. Journal of Geophysical Research 100, 22155-22171.

Semblat, J.F., Kham, M., Parara, E., Bard, P.Y., Pitilakis, K., Makra,K., Raptakis, D., 2005. Site effects: basin geometry vs soil layering.Soil Dynamics and Earthquake Engineering 25, 529-538.

Sibson, R.H., 1994. Crustal stress, faulting and fluid flow. In:Parnell, J. (Ed.), Geofluids: Origin, Migration and Evolution of Fluids in Sedimentary Basins. Special Publication, No. 78.Geological Society, London, pp. 69-84.

Sitzia, L., Bertran, P., Bahain, J., Bateman, M.D., Hernandez, M., Garon, H., de Lafontaine, G., et al., 2015. The Quaternary coversandsof southwest France. Quaternary Science Reviews 124, 84-105.

Tastet, J.-P., 1999. Le Pléistocène de la façade atlantique du Nord-Médoc (France): état des connaissances sur la lithologie et lachronostratigraphie des «Argiles du Gurp» s.l. Quaternaire 10, 199-212.

Thiel, C., Buylaert, J.P., Murray, A.S., Terhorst, B., Hofer, I., Tsukamoto, S., Frechen, M., 2011. Luminescence dating of the Stratzing loess profile (Austria) - testing the potential of an elevated temperature post-IR IRSL protocol. Quaternary International 234, 23-31.

Van Vliet-Lanoë, B., Bonnet, S., Hallegouët, B., Laurent, M., 1997. Neotectonic and seismic activity in the Armorican and Cornubian Massifs: regional stress field with glacio-isostatic influence?Journal of Geodynamics 24, 219-239. 
Van Vliet-Lanoë, B., Brulhet, J., Combes, P., Duvail, C., Ego, F., Baize, S., Cojan, I., 2017. Quaternary thermokarst and thermal erosion features in northern France: origin and palaeoenvironments. Boreas 46, $442-461$.

Van Vliet-Lanoë, B., Hibsch, C., Csontos, L., Jegouzo, S.,Hallégouët, B., Laurent, M., Maygari, A., Mercier, D., Voinchet,P., 2009. Seismically induced shale diapirism: the Mine d'Or section, Vilaine estuary, southern Brittany. International Journal of Earth Sciences 98, 969-984.

Van Vliet-Lanoë, B., Laurent, M., Bahain, J.-J., Balescu, S., Falguères, C., Field, M., Hallégouët, B., Keen, D.H., 2000. Middle Pleistocene raised beach anomalies in the English Channel: regional and global stratigraphic implications. Journal of Geodynamics 29, 15-41.

Van Vliet-Lanoë, B., Maygari, A., Meilliez, F., 2004. Distinguishing between tectonic and periglacial deformations of quaternary continental deposits in Europe. Global Planetary Change 43, 103-127.

Van Vliet-Lanoë, B., Vandenberghe, N., Laignel, B., Laurent, M., Lauriat-Rage, A., Louwye, S., Mansy, J.L., et al., 2002. Paleogeographic evolution of northwestern Europe during the Upper Cenozoic. Geodiversitas 24, 511-541.

Voinchet, P., Despriée, J, Tissoux, H., Falguères, C., Bahain, J.-J., Gageonnet, R., Dépont, J., Dolo, J.-M., 2010. ESR chronology of alluvial deposits and first human settlements of the Middle Loire Basin (Region Centre, France). Quaternary Geochronology 5, 381-384.

Wells, D.J., Coppersmith, K.J., 1994. New empirical relationships among magnitude, rupture length, rupture width, rupture area, and surface displacement. Bulletin of Seismological Society of America 84, 974 1002.

Woith, H., Wang, R., Milkereit, C., Zschau, J., Maiwald, U.,Pekdeger, A., 2003. Heterogenous response of hydrogeological systems to the Izmit and Düzce (Turkey) earthquakes of 1999. Hydrogeology Journal $11,113-121$.

Worm, H.U., 1997. A link between geomagnetic reversals and events and glaciations. Earth and Planetary Science Letters 147, 55-67.

Wyns, R., 1991. Evolution tectonique du bâti armoricain oriental au Cénozoïque d'après l'analyse des paléosurfaces continentales et des formations géologiques associées. Géologie de la France 3, 11-42.

Youd, T.L., Steidl, J.H., Nigbor, R.L., 2004. Lessons learned and need for instrumented liquefaction sites. Soil Dynamics and Earthquake Engineering 24, 639-646.

Zagwijn, W.H., 1996. The Cromerian Complex Stage of the Netherlands and correlation with other areas in Europe. In: Turner, C. (Ed.), The Early Middle Pleistocene in Europe.Balkema, Rotterdam, the Netherlands, pp. $145-172$.

Ziegler, P., Dèzes, P., 2006. Crustal evolution of western and central Europe. Geological Society, London, Memoirs 32, 43-56. 
